\title{
Exploring foreign market access in government procurement
}

\section{Anirudh Shingal}

\begin{abstract}
Using unexplored Japanese and Swiss public procurement data over 1990-2003, we examine the effect of macroeconomic, political economy, procurement-specific and domestic policy factors on governments' sourcing decisions. We also provide for an empirical test of Baldwin's $(1970,1984)$ "neutrality proposition" and for the effectiveness of the WTO's Uruguay Round Agreement on Government Procurement (URGPA) in increasing foreign market access. Our results suggest the importance of the magnitude of procurement demand, domestic firm attributes and unobserved sector-specific heterogeneity in these governments' purchases from abroad. However, the expected impact of traditional macroeconomic variables and political budget cycles does not come through in our results. Public and private sector imports do not offset each other in our analyses for Japan and only selectively for Switzerland. Finally, membership of the GPA is only found to increase the value of foreign procurement in Switzerland, though it seems to increase the import demand for contracts in both countries.
\end{abstract}

JEL classification: F10, F13, F14, D72, H57

Key words: Government procurement, home-bias, market access, GPA, Japan, Switzerland

NCCR TRADE WORKING PAPERS are preliminary documents posted on the NCCR Trade Regulation website (<www.nccr-trade.org $>$ ) and widely circulated to stimulate discussion and critical comment. These papers have not been formally edited. Citations should refer to a "NCCR Trade Working Paper", with appropriate reference made to the author(s).

Research for this paper was funded by the Swiss National Science Foundation under a grant to the National Centre of Competence in Research on Trade Regulation, based at the World Trade Institute of the University of Bern, Switzerland.

\section{FN NNF}




\title{
Exploring foreign market access in government procurement
}

\author{
Anirudh Shingal ${ }^{1}$
}

March 2012

\begin{abstract}
Using unexplored Japanese and Swiss public procurement data over 1990-2003, we examine the effect of macroeconomic, political economy, procurement-specific and domestic policy factors on governments' sourcing decisions. We also provide for an empirical test of Baldwin's (1970, 1984) "neutrality proposition" and for the effectiveness of the WTO's Uruguay Round Agreement on Government Procurement (URGPA) in increasing foreign market access. Our results suggest the importance of the magnitude of procurement demand, domestic firm attributes and unobserved sector-specific heterogeneity in these governments' purchases from abroad. However, the expected impact of traditional macroeconomic variables and political budget cycles does not come through in our results. Public and private sector imports do not offset each other in our analyses for Japan and only selectively for Switzerland. Finally, membership of the URGPA is only found to increase the value of foreign procurement in Switzerland, though it seems to increase the import demand for contracts in both countries.
\end{abstract}

JEL classification: F10, F13, F14, D72, H57

Key words: Government procurement, market access, home-bias, GPA, Japan, Switzerland

\footnotetext{
${ }^{1}$ Senior Research Fellow, WTI, University of Bern \& Research Affiliate, CARIS, University of Sussex. Address for correspondence: World Trade Institute, Hallerstrasse 6, CH - 3012, Bern, Switzerland. Tel: +41-31-6315592; Fax: +41-31-6313630; Email: anirudh.shingal@ wti.org.
} 


\section{Table of Contents}

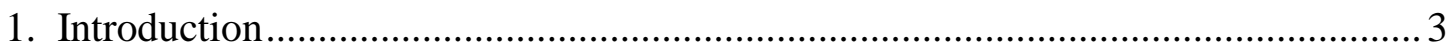

2. A simple model of procurement decision-making ............................................... 7

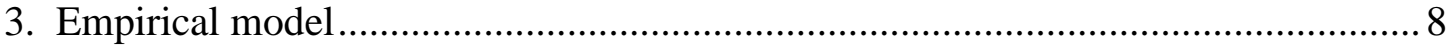

4. Data availability, limitations and preliminary diagnosis ......................................... 11

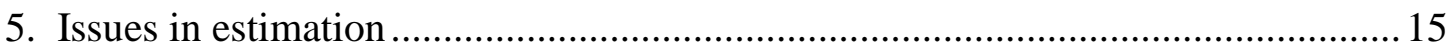

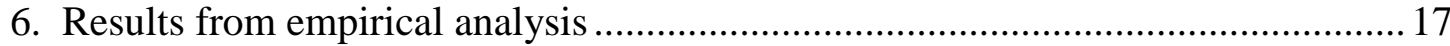

6.1. Robustness check - Secondary estimation of "pseudo" import demand for

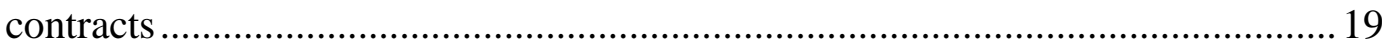

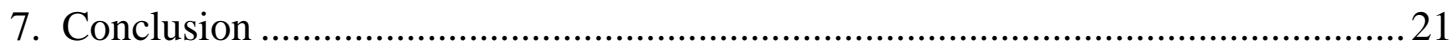

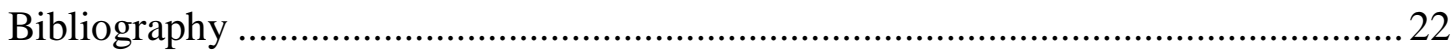

\section{List of figures and tables}

Figure 1: Distribution of foreign procurement value (real USD mn) …………..........22

Figure 2: Comparison of residual plots in estimating foreign procurement of goods . 27

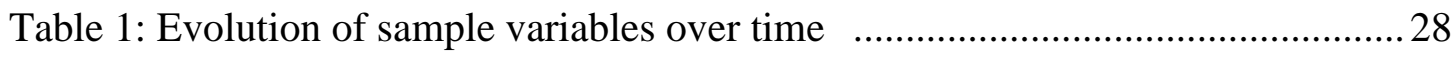

Table 2: Estimating Japanese foreign procurement value ...........................................29

Table 3: Estimating Swiss foreign procurement value …………………………........2 29

Table 4: Estimating Japanese import demand for contracts ..........................................30

Table 5: Estimating Swiss import demand for contracts ............................................... 30

\section{$\underline{\text { List of annex tables }}$}

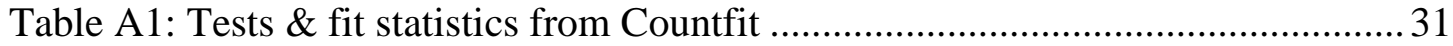

Table A2: Goods and services procured by the Japanese and Swiss governments ..... 32

Table A3: Data description for the empirical model ..................................................... 33 


\section{Introduction}

The rise in total spending by central and local governments was one of the most profound economic changes of the twentieth century (Tanzi \& Schuknecht, 2000). This also means that, in keeping with its significant responsibilities, the government in all its forms spends a considerable sum of money on procuring goods and services. The OECD (2002) has estimates suggesting that government procurement (including defence and compensation of employees) accounts for almost $20 \%$ of GDP in OECD countries and between 9 and 20\% of GDP in developing countries. Thus the state has a huge influence over the allocation of resources in market economies through procurement, a prominent aspect of which is the preference for domestic over foreign firms in the award of public contracts despite cost and quality considerations. This "home-bias" in public purchase decisions has been particularly evident in major economies during the recent economic crisis (Evenett, 2009 a, b) and has non-trivial efficiency effects especially at a time when most of these governments are confronted with binding budget constraints (Schooner \& Yukins, 2009).

Evidence in support of this home-bias has been provided in the literature - Mastanduno (1991), Hoekman and Mavroidis (1997), Trionfetti (2000), the European Commission (1997), Brülhart M. \& F. Trionfetti (2001), Evenett and Shingal (2006), Shingal (2011). Literature has also evolved to explain this home-bias in public procurement - McAfee and McMillan (1989), Laffont and Tirole (1991), Rothenberg (1993), Branco (1994), Breton and Salmon (1995), Chen (1995), Vagstad (1995), Naegelen and Mougeot (1998), Weichenrieder (2001). Another branch of this literature has looked at corruption and bribery as determinants of the home-bias in public procurement - Rose-Ackerman (1975), Rose-Ackerman (1978), Burguet and Perry (2000), Burguet and Che (2004), Compte et.al. (2005). However, almost exclusively, this literature has focused on the interaction between the tendering entity and the bidding firms in a microeconomic setting of asymmetric information and contract theory.

In this paper, we depart from this line of research and consider other factors - procurementspecific, macroeconomic, political economy and domestic policy - that influence a government's propensity to source from foreign suppliers. Review of related literature and 
anecdotal evidence both suggest the importance of these factors, but to the best of our knowledge, this area remains un-researched in the procurement literature.

The impact of political institutions on economic policy has been extensively studied in the political budget cycles literature ${ }^{2}-$ Rogoff and Silbert (1988), Persson and Tabellini (1990), Rogoff (1990), Alesina et.al. (1997), Diermeier and Merlo (1999), Blanchard and Wolfers (2000), Drazen (2000), Persson and Tabellini (2000), Shi and Svensson (2000), Persson (2002). This body of literature explores the implications of electoral cycles on the size and composition of government spending using signalling and moral hazard models to conclude that governments increase spending before elections to enhance their chances of re-election. In this paper, we extend this intuition to government procurement - governments are more likely to award contracts to domestic firms in an election period since this would improve their chances of being re-elected. Our motivation is also drawn from recent literature that looks at the effect of political connections on the allocation of procurement contracts (Goldman et.al., 2009; Hyytinen et.al., 2009) and that studying tenure in office and public procurement (Coviello \& Gagliarducci, 2010).

Similarly, the impact of macroeconomic variables, especially exchange rate, on trade has been studied in the literature (Baldwin, 1988; Baldwin \& Krugman, 1989; Campa, 2004), but not on public procurement. In this paper, we bridge this gap in research too. Governments are more likely to award contracts to domestic firms in a recession to stimulate Keynesian multiplier effects in the economy. Similarly, a currency devaluation or depreciation of the exchange rate that makes imports more expensive would also make it more cost-effective for governments to purchase from domestic firms. On the other hand, an increase in government spending at home may result in a depreciation of the real exchange rate (Ravn et. al., 2008). Thus, causality in this case may work both ways.

Anecdotal evidence cited in Shingal (2009) also suggests that the home-bias in procurement may be driven by a range of procurement-specific and domestic policy factors. These include

\footnotetext{
${ }^{2}$ An initial review of the theoretical and empirical literature can be found in Alesina et.al. (1997).
} 
the nature of the good or service ${ }^{3}$ being procured; the value of the procurement contract ${ }^{4}$; the extent of domestic competition ${ }^{5}$; practical considerations of the tender ${ }^{6}$; compliance costs ${ }^{7}$; regulatory burden ${ }^{8}$; and the domestic policy environment ${ }^{9}$ (the last three are also discussed in some detail by Evenett \& Hoekman, 2004). Of these factors, the importance of practical tender considerations and compliance costs would diminish in magnitude for foreign firms supplying governments abroad via affiliates.

To motivate our analysis, we consider a simple model of government procurement decisionmaking used in this literature to illustrate how some of these factors work to the detriment of foreign firms. We then empirically examine the importance of these factors using selfassembled and hitherto unexplored data submitted by Japan and Switzerland to the WTO over 1990-2003. In doing so, we also provide a ceteris paribus empirical test of Baldwin's (1970, 1984) "neutrality proposition" by examining if a reduction in imports from the government is

\footnotetext{
${ }^{3}$ Some goods and services are easily procurable domestically which renders the entire exercise of initiating a global tender cumbersome. On the other hand, some goods and services are too specialized for them to be available domestically, which mandates their foreign procurement. Moreover, if the structure of production is dominated by intermediate inputs, then demand is more likely to be locally-driven, giving rise to a home-bias in both consumption and trade (Hillberry \& Hummels, 2002) and this may well extend to the domain of public procurement (Brenton, 2001).

${ }^{4}$ The contract value may not be large enough to be economically attractive to foreign suppliers or to warrant a global tender, especially in the case of goods procurement.

${ }^{5}$ A competitive domestic market ensures both availability of suppliers and cost minimization through competition. In some cases, however, governments may need to restrict competition to ensure contract performance (Laffont and Tirole, 1991; Rothenberg, 1993; Breton and Salmon, 1995).

${ }^{6}$ Would the tender documentation require translation? Is there enough time to respond to the tender? Such considerations also govern the participation decisions of foreign firms besides inflating their costs.

${ }^{7}$ Breton \& Salmon (1995) show that the premium required to ensure contract compliance may increase with the number of potential bidders and in such situations minimizing expected procurement costs may require limiting the number of potential suppliers. Problems of asymmetric information may also induce procuring entities to choose suppliers located within their jurisdictions so as to reduce monitoring costs. Moreover, search costs of operating across complex networks of contacts in modern economies are likely to be lower within than between countries (Rauch, 1999) while the element of trust required in lowering transaction costs is likely to be higher (Fukuyama, 1995). All these factors act to the detriment of foreign firms.

${ }^{8}$ Cumbersome regulatory requirements can discourage a foreign firm from participating in a bid. For instance, the firm may need to be pre-registered with the domestic accreditation body before it can submit a bid. A foreign firm may also be faced with more stringent quality requirements compared to domestic firms. A study of such regulatory barriers in the EU's government procurement market can be found in Khorana and Shingal (2008). It would also be useful to remember here that services procurement depends upon the particular sector being first scheduled under the GATS; hence, there may already be a range of market access, national treatment and regulatory barriers confronting foreign suppliers in services procurement.

${ }^{9}$ Purchase and price preferences and product reservations in the importing countries systematically discriminate against foreign firms. The absence of a domestic bid challenge procedure in the importing country may also influence a foreign firm's participation decision. On the other hand, economies that are more integrated with the rest of the world are also, ceteris paribus, more likely to be open to foreign procurement.
} 
compensated by a corresponding increase in the imports of the private sector. Finally, we also test for the effectiveness of the WTO's Uruguay Round Agreement on Government Procurement (URGPA) in increasing foreign market access in these countries' goods procurement market. To the best of our knowledge, these are all original contributions to this literature.

The choice of countries in this paper is primarily determined by data availability. Both countries have submitted detailed procurement data sufficiently regularly ${ }^{10}$ over 1990-2003 and in a form amenable to empirical analysis. But there are other considerations as well: both are large open economies and have large governments, federal as well as sub-federal.

Across specifications, our empirical results suggest the importance of the magnitude of procurement demand and unobserved sector-specific heterogeneity in the public purchase patterns of both countries. Foreign procurement is found to vary inversely with domestic firm competitiveness and other supply-side controls in Japan in the absence of sector-specific fixed effects (SSFE); the opposite is true for Switzerland. However, the expected impact of macroeconomic factors and political budget cycles does not come through in our results. Public and private sector imports do not offset each other in our analyses for Japan and only selectively for Switzerland. Finally, membership of the URGPA is only found to increase foreign market access for goods in Switzerland, though it does seem to increase the import demand for contracts in both countries.

The rest of this paper is structured as follows. Section 2 considers a formal treatment of a government's procurement decision while Section 3 introduces the empirical model used in the paper. Section 4 discusses the data used and its limitations for analysis and also conducts a preliminary diagnosis. Section 5 discusses relevant estimation issues with Section 6 describing results from the empirical analysis. Section 7 concludes.

\footnotetext{
${ }^{10}$ Japanese procurement data are missing for 1994-1996, the Swiss for 1992.
} 


\section{A simple model of procurement decision-making}

Government procurement rules at the WTO require that only contracts above a certain threshold $^{11}$ value be subject to internationally competitive bidding (ICB). One way of discriminating against foreign firms is by splitting contracts to keep them below such thresholds.

More formally, consider a government wishing to purchase a good or service whose value is given by $\mathrm{V}(\mathrm{q}, \mathrm{p})$ where $\mathrm{q}$ is the characteristics/quality, $\mathrm{p}$ is the expected payment or the price vector. Let the "splitting" parameter be w and the preferences to the domestic firms be s where $\mathrm{s} \in(0,1)$. Denote the costs of the bidding process by $\mathrm{k}$.

Now in the absence of contract splitting and preferential treatment, a procurement contract is subject to ICB if $\mathrm{V}(\mathrm{q}, \mathrm{p})>\mathrm{k}$; this describes the threshold condition.

Allowing for contract splitting and preferences the threshold condition becomes $[1-(w+s)] . V(q, p)>k$

Implication 1: If the preferential treatment is absolute i.e. $s=1$, then the contract is not subject to ICB

Implication 2: As $w \rightarrow 1$, the contract remains below threshold

\footnotetext{
${ }^{11}$ Thresholds differ depending on the type of procurement and on the level of government making the purchase and are stated in terms of the IMF's accounting unit, the SDR. For central government entities, the threshold values are SDR 130,000 for procurement of goods and services and SDR 5 million for procurement of construction services. For sub-central government entities, the thresholds are SDR 200,000 for goods and services, (except for the United States and Canada which apply a SDR 355,000 threshold) and SDR 5 million for construction services (with the exception of Japan and the South Korea, which apply a SDR 15 million threshold). For utilities, the threshold values are SDR 400,000 for goods and services (with the exception that the United States applies a US\$250,000 threshold for federally owned utilities) and SDR 5 million for construction services (barring Japan and Korea, which apply a threshold of SDR 15 million). Additionally, Annexes of individual signatories may specify higher thresholds for particular Contracting Parties in a bid to ensure reciprocity.
} 
Another way of discriminating against foreign firms is to award fewer of the above-threshold contracts to foreign suppliers. Let the cost of producing the procured good or service for the domestic and foreign firm be $c_{d}(q)$ and $c_{f}(q)$, respectively with $c_{f}()<.c_{d}($.$) by assumption. Let$ factors increasing the cost of participation for foreign suppliers relative to domestic suppliers be denoted by $\mathrm{z}(\mathrm{V}()$.$) and the government's corruption propensity by \mathrm{m}$.

Then, expected profit of the domestic firm, $\pi_{\mathrm{d}}=\mathrm{p}-\left[\mathrm{c}_{\mathrm{d}}(\mathrm{q})+\mathrm{m}(\mathrm{V}()).\right]$, and expected profit of the foreign firm, $\pi_{\mathrm{f}}=\mathrm{p}-\left[\mathrm{c}_{\mathrm{f}}(\mathrm{q})+\mathrm{z}(\mathrm{V}())+.\mathrm{m}(\mathrm{V}()).\right]$. Thus, even if $\mathrm{c}_{\mathrm{f}}()<.\mathrm{c}_{\mathrm{d}}(),. \pi_{\mathrm{f}}<\pi_{\mathrm{d}}$ if $\mathrm{z}(\mathrm{V}())>.\left(\mathrm{c}_{\mathrm{d}}-\mathrm{c}_{\mathrm{f}}\right)$. The foreign firm may therefore decide not to participate in the bidding process itself, which is an illustration of how the home-bias works.

Similarly, the government's objective is to maximize the expected value of $[\mathrm{V}(\mathrm{q}, \mathrm{p})-\mathrm{p}]$, which is equivalent to minimizing the expected payment as each bidder will choose the cost minimizing quality. Now, $\mathrm{p}=\mathrm{f}\left(\mathrm{b}_{\mathrm{d}}, \mathrm{b}_{\mathrm{f}}\right)$ where $\mathrm{b}_{\mathrm{d}}, \mathrm{b}_{\mathrm{f}}$ are the bid prices of the domestic and foreign firm, respectively, and $b_{d}=g\left(c_{d}().\right)$ and $b_{f}=h\left[\left(c_{f}(),. z(V()).\right]\right.$. Even in the absence of $\mathrm{z}(\mathrm{v}()$.$) , McAfee \& McMillan (1989) and Branco (1994) have shown that the optimal$ procurement policy implies that the contract be awarded to the domestic firm. With $\mathrm{z}(\mathrm{V}())>.\left(\mathrm{c}_{\mathrm{d}}-\mathrm{c}_{\mathrm{f}}\right)$, minimizing expected payment would necessarily imply that the government award the contract to the domestic firm.

\section{Empirical model}

Ideally, the empirical estimation would entail a two-stage Heckman selection model, where stage one would estimate whether (or not) a procuring entity put a contract above threshold and stage two would estimate the share of the above-threshold contracts that was awarded to foreign suppliers. Unfortunately, available government procurement data meet the requirements of stage two analysis only; data required for stage one analysis are not required by the URGPA to be reported at the level of the individual goods and services. 
The empirical analysis in this paper therefore only focuses on stage two. The determinants of foreign procurement discussed in the preceding sections are the explanatory variables used in our empirical model. The functional form and specification of the model are in the spirit of the standard import demand function of the following form:

$\ln \mathrm{MD}_{\mathrm{it}}=\mathrm{a}_{0}+\mathrm{a}_{1} \ln \left(\mathrm{PM}_{\mathrm{i}} / \mathrm{PD}_{\mathrm{i}}\right)_{\mathrm{t}}+\mathrm{a}_{2} \ln \mathrm{Y}_{\mathrm{it}}+\mathrm{U}_{\mathrm{it}}$,

where $\mathrm{MD}_{\mathrm{it}}$ is the value of imports of country "i" at time " $\mathrm{t}$ ", $\mathrm{PM}$ is the unit value of imports, PD is the domestic price level, $\mathrm{Y}$ is the real GNP, and $\mathrm{U}_{\mathrm{it}}$ is an error term associated with each observation.

However, we do not pool data for Japan and Switzerland in one panel as these countries are sufficiently different to warrant this ${ }^{12}$. Moreover, data availability constraints, discussed in detail in the following section, imply that doing so would lead to biased results. We therefore set up the data in separate panels for Japan and Switzerland to gain information from both the variation in time and that across categories of goods and services that are procured by the governments of these two countries. The empirical model has the following baseline specification:

$$
\begin{aligned}
& \mathrm{FPV}_{\mathrm{kt}}=\alpha+\beta_{1} \mathrm{RDN}^{13}{ }_{\mathrm{kt}}+\beta_{2} \mathrm{APL}_{\mathrm{kt}}+\beta_{3} \mathrm{X}_{\mathrm{kt}}+\beta_{4} \mathrm{XD}_{\mathrm{kt}}+\beta_{5} \mathrm{~N}_{\mathrm{kt}}^{14}+\beta_{6} \mathrm{TAR}_{\mathrm{kt}}^{15}+\beta_{7} \mathrm{M}_{\mathrm{kt}}+\beta_{8} \mathrm{ROG}_{\mathrm{t}}+ \\
& \beta_{9} \mathrm{REER}_{\mathrm{t}}{ }_{\mathrm{t}}+\beta_{10} \mathrm{ELEC}_{\mathrm{t}}+\beta_{11} \mathrm{ELEC}_{\mathrm{t}-1}+\beta_{12} \mathrm{URGPA}_{\mathrm{t}}+\mu_{\mathrm{kt}}
\end{aligned}
$$

\footnotetext{
${ }^{12}$ The Japanese economy has a larger government and is also less open then Switzerland. The average share of total government expenditure in GDP over 1990-2003 was almost 50\% in Japan versus 37\% in Switzerland, while the average share of trade in GDP in these economies was 19.2 and $74.6 \%$, respectively, over this time period.

${ }^{13}$ The relative demand variable, described in the text, takes the value zero for $4.6 \%$ of the observations in the case of Japan and $22.8 \%$ of the observations in the case of Switzerland.

${ }^{14}$ The number of firms (N) is excluded in the estimation for Switzerland as data on this variable is available only for $20 \%$ of the observations.

${ }^{15}$ The simple average applied tariff (TAR) is effectively zero in the case of Switzerland, so this variable is excluded while estimating the foreign procurement of Swiss goods. In the case of Japan, this variable takes the value zero in $48.4 \%$ of the observations.

${ }^{16}$ An increase in REER means currency appreciation and loss in competitiveness.

${ }^{17}$ The URGPA dummy is only used in the goods estimation. Since the coverage of services in the GPA only began with the Uruguay Round, the URGPA dummy is rendered redundant in the services estimation.
} 
where " $k$ " denotes the industry/services sector (henceforth simply referred to as "sector") and all economic data are expressed in real USD using the US GDP Implicit Price Deflator.

In our empirical model, the value of the government's foreign procurement is the dependent variable, FPV. In the absence of data on the price of individual government contracts awarded to domestic and foreign firms, we use several supply-side sector-specific controls such as average productivity of labour (APL), number of firms $(\mathrm{N})$, value of exports (X), number of export destinations (XD) and tariffs (TAR) as proxies for domestic firm competitiveness. Economy-wide income and prices effects are represented by macroeconomic variables such as annual rate of GDP growth (ROG), unemployment rate (UNEMP) and exchange rates (REER). In addition, we also control for political economy factors like election cycles (dummy variables for election years of the Japanese House of Representatives and the Swiss Parliament, and for the year preceding these election years; $\mathrm{ELEC}_{\mathrm{t}}, \mathrm{ELEC}_{\mathrm{t}-1}$ ) and for the role of the WTO's URGPA (URGPA dummy). Finally, to control for the magnitude of procurement demand in a particular sector, we construct a relative demand variable (RDN), which is the ratio of the number of contracts awarded in a particular sector to the total number of contracts awarded in a year. Our empirical model also tests whether any increase in public sector imports (FPV) is offset by a decline in private sector imports (M) for the "covered" goods and services, which essentially provides a ceteris paribus test of Baldwin's "neutrality proposition".

A priori, we expect the signs of $\beta_{1}, \beta_{9}$ and $\beta_{12}$ to be positive and $\beta_{2}$ through $\beta_{6}, \beta_{10}$ and $\beta_{11}$ to be negative. A positive sign on the $\beta_{7}$ coefficient would suggest that public and private sector imports were not substitutes and a positive sign on the $\beta_{8}$ coefficient would suggest that governments purchased fewer contracts from foreign firms during periods of economic slowdown alluding to possible government efforts at aggregate demand management. It may be useful to point out that only domestic firm attributes such as an increase in the productivity of the domestic firms would be considered as non-discriminatory reasons for governments purchasing fewer goods and services from abroad. Most of the other factors for a decline in foreign procurement would, on the other hand, suggest the presence of a home-bias. 
We also progressively control for unobserved time- and sector-specific heterogeneity in a fixed effects specification:

$\mathrm{FPV}_{\mathrm{kt}}=\alpha_{\mathrm{t}}+\alpha_{\mathrm{k}}+\beta_{1}{ }^{\prime} \mathrm{RDN}_{\mathrm{kt}}+\beta_{2}{ }^{\prime} \mathrm{APL}_{\mathrm{kt}}+\beta_{3}{ }^{\prime} \mathrm{X}_{\mathrm{kt}}+\beta_{4}{ }^{\prime} \mathrm{XD}_{\mathrm{kt}}+\beta_{5}{ }^{\prime} \mathrm{N}_{\mathrm{kt}}+\beta_{6}{ }^{\prime} \mathrm{TAR}_{\mathrm{kt}}+\beta_{7}{ }^{\prime} \mathrm{M}_{\mathrm{kt}}+\mu_{\mathrm{kt}}^{\prime}$

and finally, allow the sector-specific fixed effects (SSFE) to vary according to a linear trend: $\mathrm{FPV}_{\mathrm{kt}}=\alpha_{\mathrm{t}}^{\prime \prime}+\alpha_{\mathrm{k} . \text { trend }}+\beta_{1}{ }^{\prime \mathrm{RDN}_{\mathrm{kt}}}+\beta_{2}{ }^{\prime \prime} \mathrm{APL}_{\mathrm{kt}}+\beta_{3}{ }^{\prime \prime} \mathrm{X}_{\mathrm{kt}}+\beta_{4}{ }^{\prime \prime} \mathrm{XD}_{\mathrm{kt}}+\beta_{5}{ }^{\prime \prime} \mathrm{N}_{\mathrm{kt}}+\beta_{6}{ }^{\prime \prime} \mathrm{TAR}_{\mathrm{kt}}+\beta_{7} \mathrm{M}_{\mathrm{kt}}$ $+\mu{ }_{k t}$

\section{Data availability, limitations and preliminary diagnosis}

Statistics submitted by the URGPA signatories to the WTO Secretariat are the primary source of data on government procurement. Article XIX: 5 of the URGPA requires that Contracting Parties submit procurement-related data to the Committee on Government Procurement. Unfortunately, only half of the 40 Contracting Parties (Canada, the EC, Hong Kong, Japan, Norway and the United States) have submitted these data regularly since the Uruguay Round, especially over $1997-2007^{18}$. Moreover, these submissions have been made electronically only since the Uruguay Round, which meant that the database for analysis in this paper before the year 1996 was assembled manually.

Even amongst the countries that have submitted these data, there are significant differences, both in terms of what is included and how it is included ${ }^{19}$, and the need for consistency, has thus determined the choice of sample countries for the analysis in this paper. For both Japan and Switzerland, we consider all goods and services, including construction, included by them in Annexes 1, 4 and 5 of Appendix 1 of the URGPA; the list is provided in Annex Table A2 of this paper.

\footnotetext{
${ }^{18}$ Switzerland has not provided data beyond 2003. A snapshot of country procurement submissions is available in Shingal (2011).

${ }^{19}$ For instance, Norway and the US employ a different classification system compared to the EC, Japan and Switzerland which makes it impossible to analyze data at the level of the disaggregated good or service before the year 2008. Canada too uses a different classification system for services and provides no information on suppliers, so the amount of foreign procurement in services cannot be calculated. Hong Kong's submissions until the year 2008 have restricted access.
} 
Sector-specific data on goods purchased by these two governments are taken from three different sources. Data on goods output, employment and number of firms in Japan are sourced from OECD STAN (various years) and Nicita \& Olarreaga (2006) for the period 1990-93 and from UNIDO (2010) 1994 onwards. Data on goods output in Switzerland are taken from Nicita \& Olarreaga (2006) for the period 1991-96 and from UNIDO (2010) and OECD STAN (various years) for the period 1997-2003. Data on goods employment in Switzerland are taken from UNIDO (2010) and OECD STAN (various years) and that on the number of firms from UNIDO (2010). The last were available only for the period 1997-2003 and that too were rather scant; the variable was therefore excluded from analysis.

Sector-specific goods trade data on Japan are taken from OECD STAN (various years) and those on tariffs from Nicita \& Olarreaga (2006). Swiss trade data are taken from OECD STAN (various years) and Nicita \& Olarreaga (2006). Swiss tariffs on the goods included in our analysis are zero. Data on sector-specific services output and employment for the two countries are taken from OECD STAN (various years) and those on trade from OECD Trade in Services by Service Category (various years). Sector-specific data on the number of export destinations for both countries are compiled from UN Comtrade for goods trade and from IIDE (2009) for services trade.

Data availability imposed significant constraints on our analysis, since we needed sectorspecific information on output, employment and trade for the two countries for the same sectors of goods and services over 1990-2003 and then needed to map this information with that on foreign procurement. To begin with, there were definitional issues for both goods and services, which assumed importance as we needed to achieve consistency across different classification systems used in the data sources ${ }^{20}$. Then in some cases, sector-specific output, employment and trade data were not available at the level of the individual goods sectors that these two governments purchased, which meant that data needed to be aggregated into broader sectors to enable meaningful analysis. This was especially true of sectors 11-13 and 22, 24 and 25 for both countries. In some of these cases, however, more disaggregated data were available for exports but not for output or employment (and vice versa); thus, wherever

\footnotetext{
${ }^{20}$ The concordances used in this paper are taken from Shingal (2011).
} 
possible, the aggregated data for output and employment were disaggregated using the export data (and vice versa).

Despite all these efforts, a few goods sectors in both countries still had sector-specific output, employment, trade and tariff data missing. For instance, there were no data on output, employment, number of firms or trade for sectors 2 and 21 amongst the goods that the Japanese procured; tariff data were unavailable for sectors 2, 4, 14-15 and 21 over 1990-96 and for sectors 2, 4, 14-15 and 21-22, 1997 onwards. In the case of Switzerland, goodsspecific data on output and employment were unavailable for sectors 2, 4, 10, 14-15 and 17-26 over 1990-96; for sectors 2, 4, 10, and 18-21 for the year 1997; and for sectors 2-4, 9-10 and 18-21 over 1998-2003. Trade data were missing for sectors 2 and 21 across this entire time period.

As in the case of goods, sector-specific data on output, employment and trade were not available for all services sectors. In this case too, the individual services sectors were aggregated into broader sectors ${ }^{21}$ to enable meaningful analysis. Even then, the absence of trade data for Swiss construction and computer-related services over the sample period meant that the effective sample size was further truncated in the case of Switzerland. This also led to relatively few services observations in the sample for both countries, due to which results from the empirical analysis that follows for services alone are more suggestive than conclusive.

Annex Table A3 shows the mean value for the sample variables, along with their minimum, maximum and the standard deviation, for both Japan and Switzerland. Procurement data are reported in the country submissions in terms of Special Drawing Rights, the IMF's accounting unit. These values have thus first been converted to USD using exchange rates from the IMF's International Financial Statistics (various years). All economic data are reported in real terms using the US GDP implicit price deflator. As this table shows, there is lot of diversity in the availability of data on the variables used in the model, leading to several missing values,

\footnotetext{
${ }^{21}$ This yielded seven broad services sectors for Japan [construction (41), maintenance \& repair (51-52), OBS (42, $72-73,75-77)$, transportation (53-57), communication (58, 61-65), computer-related (66-67, 71) and sewage \& sanitation (78)] and six for Switzerland [construction, OBS (1, 8-18), financial (6), transportation (2-4), communication (5) and computer-related (7)].
} 
especially for sector-specific variables. We are thus left with unbalanced panels for both Japan and Switzerland.

Comparing the evolution of these procurement metrics over 1990-2003 with that of the other sample variables in Table 1, we find that the decline in the share of FP in AT procurement of goods in both countries was accompanied by a considerable rise in the labour productivity of the domestic firms (from USD 126,000 to USD 328,000 in Japan and from USD 114,000 to USD 278,000 in Switzerland) and by a significant fall in the number of domestic firms (46.3\% in Japan and $38.4 \%$ in Switzerland). At the same time, the annual rate of economic growth fell sharply in both countries, the unemployment rate went up considerably and the REER also appreciated by $6 \%$ over $1990-2003$. This preliminary diagnosis goes partly with our model's predictions and suggests that these governments' sourcing decisions were driven as much by domestic firm attributes as by fluctuations in macroeconomic fundamentals. On the other hand, our model's predictions seem to hold less well for services, where a rise in domestic firm productivity is still accompanied by a rise in the share of foreign procurement. However, given that our data set is less complete for services, these results are also likely to be less conclusive. This said, for both goods and services, the import propensities move in an opposite direction to FP shares, which suggests that Baldwin's "neutrality proposition" may hold good in both countries, but the multivariate analysis that follows would provide a better test of that.

\section{<Insert Table 1 here >}

Finally, we exclude Swiss services procurement in 2003 from the empirical analysis that follows as that year was a statistical outlier in the Swiss procurement pattern (Shingal, 2011), characterized by an unusual purchase of high-value technical, scientific and consulting services from foreign firms. However, our empirical results remain qualitatively identical even without this adjustment to the sample data. 


\section{Issues in estimation}

The choice of estimation technique was primarily governed by the characteristics of our sample data. Prima facie, our data was characterized by both over-dispersion and excess zeroes which rendered a log-linear OLS estimation biased ${ }^{22}$ and meant that we needed to consider non-linear techniques such as those suitable for count data estimation.

Over-dispersion in the raw data is the result of unobserved heterogeneity (Greene, 1994) and the description is used for data where the conditional variance is in excess of the conditional mean. Untreated over- or under-dispersion results in consistent, yet inefficient, estimates characterized by spuriously large z-values and spuriously small p-values due to downward biased standard errors (Gourieroux et al., 1984; Cameron and Trivedi, 1986). We found our data on foreign procurement value to be strongly skewed to the right for both Japan and Switzerland (Figure 1). The variance-to-mean ratio was found to be 139 in the case of Japanese FPV and 43.4 in the case of Swiss FPV.

Data is said to suffer from "excess zeroes" when the number of zeroes in the raw data is greater than what the Poisson or NB distributions can predict and is the result of an overabundance of zeroes, suggesting that some of the zeroes in the data may be generated by a different process. Our dependent variable was found to be zero for $29.4 \%$ of the observations in the case of Japan and $49.4 \%$ of the observations in the case of Switzerland.

Treatment of count data with over-dispersion and excess zeroes offers three estimation possibilities - the Negative Binomial (NB), the Zero-Inflated Poisson (ZIP) and the ZeroInflated Negative Binomial (ZINB). The NB allows for between-subject heterogeneity, but the ZIP does not. However, as opposed to the NB, the zero-inflated models allow for different

\footnotetext{
${ }^{22}$ Using a log-linear model would effectively truncate the size of the sample (because the log of zero is not defined) and hence, yields biased estimates. One way to solve this problem would be by adding a small positive constant to all zero values of the dependent variable (normally this is done by adding 1 to all zeroes because $\log (1)=0$ ), but this would not only amount to data manipulation but would also bias the estimates if the incidence of zeroes was correlated with other observed or unobserved factors i.e. if there was some economic rationale for the incidence of zeroes (for e.g. in the context of gravity model estimations, Baldwin and Harigan (2008) have shown the export zeroes to be strongly correlated with distance and size of the importing country).
} 
data-generating processes for zero and non-zero count data and in that, may be theoretically more appropriate for our analysis as they allow for the possibility of foreign procurement being zero in a good/service sector because there were no foreign suppliers and/or there were differences in preferences and/or quality as opposed to foreign procurement being zero because the foreign suppliers were less-competitive.

However, when we compared the three available choices using the Countfit function in Stata (Long \& Freese, 2005), the test and fit statistics reported in Annex Table A1 ${ }^{23}$ suggested that the NB was the best estimator for both our primary and secondary (see Section 6.1 below) estimations in the baseline specifications. ${ }^{24}$ Moreover, when we estimated our primary and secondary equations using either the ZIP or the ZINB, the standard errors on the coefficients in the inflation equations (those predicting certain zero FP) were found to be very large, suggesting a definite lack of fit of either model to our data for both countries ${ }^{25}$. This further corroborated our choice of the NB as the preferred estimator for our baseline specifications and suggested that our raw data were possibly only characterized by over-dispersion ${ }^{26}$ and not by excess zeroes.

The related issue in our fixed effects specification was the choice between the conditional/panel and the unconditional fixed effects negative binomial (FENB). Literature suggests that the conditional/panel FENB is not a "true FE" model (Allison \& Waterman, 2002) as it requires a specific functional relationship between the individual FEs and the

\footnotetext{
${ }^{23}$ This table only reports results from the primary goods estimation in both countries as goods both dominate and have the more complete data in our sample. As it turned out, services observations were not sufficient to successfully implement the Countfit function in Stata, especially in the secondary estimation.

${ }^{24}$ The plot of residuals (Figure 2 shows this only for the primary goods estimation) suggested that the ZINB and NB were preferable to the ZIP (with the latter considerably under-estimating the probability of zero counts). Further, in all cases, the residual plots for the NB and ZINB were found to be identical especially for counts exceeding one, with the NB providing a better fit at count zero. Moreover, while the Vuong statistic (Vuong, 1989) suggested a statistically significant preference for ZINB over NB, the Bayesian Information Criterion suggested a strong preference for the NB over ZINB. Finally, while the plot of residuals suggested the ZIP to be the preferred estimator in the primary estimation for Japan, the following footnote and the associated text explains why we still chose the NB.

${ }^{25}$ The large negative coefficients at the lower bound of the confidence intervals of the inflation equation meant that the $\mathrm{xb}$ vector would take on large negative values when evaluated at this lower bound so that the value of its cumulative distribution function would essentially be zero. At zero value, the zero-inflated models fail to model over-dispersion in the raw data, so the ZINB reduces to NB and the ZIP to Poisson (Long, 1997).

${ }^{26}$ In fact, the generally statistically significant non-zero values of the over-dispersion parameter (alpha) in the empirical results that follow confirm this finding, especially for non-services.
} 
individual over-dispersion parameter to cancel out the FEs and there is no a priori reason to assume that this would be the case (Guimarães, 2008). Hence, introducing FEs via sectorspecific dummies in the NB model is superior to the conditional/panel FENB and does not even suffer from any "incidental parameter" bias (Allison \& Waterman, 2002). We thus estimated our FEs specifications using the unconditional FENB.

\section{Results from empirical analysis}

The results from the primary estimation carried on Japanese data are reported in Table 2 and those on Swiss data in Table 3. In each of these tables, columns I-IV report results for goods and services together, columns V-VIII report results for only goods and columns IX-XII for only services. In each case, we begin by estimating the baseline specification, then progressively control for year fixed effects, time-invariant year and sector-specific fixed effects and finally allow the SSFE to vary according to a linear trend. All tables report robust estimates to account for the heteroskedasticity in the raw data for both countries. Finally, the NB is a log-linear model that, like the logit, has an odds-ratio interpretation for the estimated coefficients.

\section{<Insert Tables 2 and 3 here>}

Across most specifications, our results suggest the overwhelming importance of the magnitude of procurement demand in explaining foreign public procurement of goods and services. For instance, a $1 \%$ unit increase in our relative demand variable raises the value of foreign procurement of Japanese goods and services in the baseline specification 11 times $^{27}$, ceteris paribus and on average. The estimated coefficients reduce considerably in magnitude when the estimating equations include time-invariant SSFE, thereby suggesting that not controlling for unobserved sector-specific heterogeneity biases these results upwards. Thus, unobservables such as the price, quality or even the nature of the good/service being procured seems to explain some of the variation in foreign procurement value that was earlier explained

\footnotetext{
${ }^{27}$ This is calculated as $[\exp (7.0)-1]$. In general, for explanatory variable $\mathrm{X}_{\mathrm{k}}$, the percentage change in $\mathrm{Y}$ for a $\delta$ unit change in $X_{\mathrm{k}}$ is given by $\left[\exp \left(\beta_{\mathrm{k}}^{*} \delta\right)-1\right] * 100$.
} 
by the relative demand variable, which is also what anecdotal evidence (Shingal, 2009) suggests.

Japanese foreign procurement of goods and services separately varies inversely with domestic supply-side controls ${ }^{28}$ of labour productivity, export value and tariffs in the absence of SSFE. However, once these effects are included in estimation, foreign procurement value moves in the same direction as these controls, a result that goes against our model's predictions ${ }^{29}$. This seems to suggest that the quality or nature of the good/service to be procured swamped domestic firm competitiveness in determining the Japanese government's propensity to source from abroad. In the case of Switzerland, foreign procurement value generally varies directly with supply-side controls of exports and the number of export destinations and foreign procurement of non-services varies directly with labour productivity. These are all counterintuitive outcomes that seem to suggest that efficiency attributes may not have had a bearing on Swiss governments' purchase decisions during this period. However, the results for labour productivity are reversed with time-invariant SSFE. This seems to suggest that rising domestic firm competitiveness translated into lower Swiss foreign procurement of goods of a specific nature or quality.

Public and private sector imports are not found to offset each other in the case of Japanese goods. However, the increase in foreign procurement in the SSFE specification for Swiss goods seems to be at the expense of private sector imports. Specifically, a one unit increase in private sector imports lowers the value of foreign procurement of Swiss goods by $0.05 \%$, ceteris paribus and on average (Column VII, Table 3). This is the only evidence of our sample data meeting Baldwin's "neutrality proposition" in our primary estimation.

On the whole, our results do not provide much support for the role of economic growth rates, exchange rates, electoral cycles \& the URGPA in determining Japanese foreign procurement value. In the case of Switzerland on the other hand, foreign procurement, at least of services, is

\footnotetext{
${ }^{28}$ The result with respect to the number of firms is as expected but lacks statistical significance; in the case of the number of export destinations, however, the result is counter-intuitive and statistically significant for goods with SSFE.

${ }^{29}$ With trend-varying SSFE, we again get the expected results.
} 
found to be negatively correlated with economic growth; exchange rate appreciation seems to have a negative effect on foreign procurement in general; and foreign procurement of services seems to go up in the year preceding the election year. The last two results go against our model's predictions and may suggest greater discrimination in the award of public contracts by Swiss governments.

The coefficient on the URGPA dummy is positive and statistically significant for Swiss goods procurement, which suggests that the disciplining mechanisms of the URGPA may have led to greater foreign access to that government's goods procurement market. Specifically, the postURGPA years saw a $103.4 \%$ greater value of foreign goods procurement relative to the preURGPA years, ceteris paribus and on average. However, we do not find a similar positive statistically significant effect for Japan.

\subsection{Robustness check - Secondary estimation of "pseudo" import demand for contracts}

As a robustness check, we also estimate a separate pseudo-import demand function of procurement contracts in a secondary estimation. The dependent variable in this secondary estimation is the number of contracts purchased from foreign suppliers (MDD). In addition to the control variables used in the primary estimation, we include the average value ${ }^{30}$ of a contract procured domestically (PD) and internationally (PF) in the secondary estimation in both the baseline and fixed effects specifications. PD and PF are expected to impact, negatively and positively, respectively, on the pseudo-import demand for contracts given that a larger value contract is expected to be more attractive to a bidding firm. The baseline specification for the secondary estimation is as follows:

$$
\begin{aligned}
& \mathrm{MDD}_{\mathrm{kt}}=\alpha^{\prime}+\gamma_{1} \mathrm{RDV}^{31}{ }_{\mathrm{kt}}+\gamma_{2} \mathrm{PD}_{\mathrm{kt}}+\gamma_{3} \mathrm{PF}_{\mathrm{kt}}+\gamma_{4} \mathrm{APL}_{\mathrm{kt}}+\gamma_{5} \mathrm{X}_{\mathrm{kt}}+\gamma_{6} \mathrm{XD}_{\mathrm{kt}}+\gamma_{7} \mathrm{~N}_{\mathrm{kt}}+\gamma_{8} \mathrm{TAR}_{\mathrm{kt}}+ \\
& \gamma_{9} \mathrm{M}_{\mathrm{kt}}+\gamma_{10} \mathrm{ROG}_{\mathrm{t}}+\gamma_{11} \mathrm{REER}_{\mathrm{t}}+\gamma_{12} \mathrm{ELEC}_{\mathrm{t}}+\gamma_{13} \mathrm{ELEC}_{\mathrm{t}-1}+\gamma_{14} \mathrm{URGA}_{\mathrm{t}}+\delta_{\mathrm{kt}}
\end{aligned}
$$

\footnotetext{
${ }^{30}$ Given that data are also available on the number of contracts purchased from domestic and foreign suppliers, we calculate the average value of a contract procured domestically and internationally by dividing the total contract value purchased from domestic and foreign suppliers by the respective number of procurement contracts. ${ }^{31}$ The relative demand variable in the secondary estimation is constructed with respect to contract value as the ratio of the value of contracts awarded in a particular sector to the total value of contracts awarded in a year.
} 
Table 4 reports the results of the secondary estimation for Japan and Table 5 for Switzerland. The results from this estimation confirm the findings from the primary estimation with respect to the importance of the magnitude of procurement demand and unobserved sector-specific heterogeneity, the mixed relationship with domestic supply-side controls, the nonsubstitutability of public and private sector goods imports in the case of Japan, and the general lack of response of Japanese public purchases to macroeconomic factors and political budget cycles.

\section{<Insert Tables 4 and 5 here>}

The biggest turnaround in these results, however, emerges in the coefficients on the URGPA dummy. Unlike in the primary estimation, the URGPA seems to have fostered import demand for Japanese goods contracts and made it more robust for Swiss goods ${ }^{32}$. This result, coupled with the opposite finding from the primary estimation of foreign procurement value at least in the case of Japan, suggests that the disciplining mechanisms of the URGPA may have been more successful in increasing import demand for those goods contracts where the average contract value was not large.

Finally, looking at the impact of average contract value on the import demand for contracts, we find that the impact of the average value of a contract awarded to a domestic firm is statistically insignificant for goods procurement in both countries. The average value of a contract awarded to a foreign firm has a negative impact on the import demand for Japanese and Swiss goods, but a generally positive effect on their import demand for services. This last result for goods is counter-intuitive and seems to suggest that foreign firms may be in these goods procurement markets irrespective of average contract value.

\footnotetext{
32 The post-URGPA years saw an $82.2 \%$ and $249 \%$ larger import demand for goods contracts relative to the preURGPA years in the case of Japan and Switzerland, respectively, ceteris paribus and on average.
} 


\section{Conclusion}

In this paper, we analyze procurement data submitted by Japan and Switzerland to the WTO over the period 1990-2003 for the effect of macroeconomic, political economy, procurementspecific and domestic policy factors that may have influenced these governments' sourcing decisions from abroad. To the best of our knowledge, this is also the first empirical test of the effectiveness of the URGPA in increasing market access for foreign suppliers and of the ceteris paribus substitutability of public and private sector imports.

Our first major conclusion is that the most important factors that have a bearing on governments' sourcing decisions are those related to domestic firm attributes and the magnitude of procurement demand. The expected role of macroeconomic factors and political budget cycles does not come through in our empirical analysis. The non-substitutability between Japanese public and private sector imports seems to suggest that this government's demand exceeded the undistorted free trade level of domestic supply during this period (Evenett \& Hoekman, 2005). The opposite finding for Switzerland, on the other hand, points to a home-bias in that government's purchase patterns.

Our model's predictions on the impact of domestic firm attributes seem to be met more by Japanese data than the Swiss; our findings on the impact of exchange rates and electoral cycles too suggest that Swiss public purchase patterns may have been more discriminatory towards foreign suppliers during these years than those of the Japanese.

Finally, though the URGPA requires that contracts above a certain minimum threshold value be subject to internationally competitive bidding, this does not always ensure that high value contracts are awarded to foreign suppliers, even if the latter were more efficient, which underlines the scope for plugging this loophole in possible reform of this agreement. 


\section{Bibliography}

Alesina, A., N. Roubini \& G. Cohen (1997). Political Cycles and the Macroeconomy, Cambridge, MA: MIT Press.

Allison, P.D. \& R. Waterman (2002). 'Fixed-effects Negative Binomial Regression Models,' Sociological Methodology 32:1, 247-265.

Baldwin, R. (1988). 'Hysteresis in Import Prices: The Beachhead Effect,' The American Economic Review 78:4, pp 773-785.

Baldwin, R.E. (1970). Non-tariff Distortions of International Trade, Washington, DC: Brookings.

Baldwin, R.E. (1984). 'Trade policies in developed countries,' in Jones, R., Kenen, P. (Eds.), Handbook of International Economics, North-Holland, Amsterdam.

Baldwin, R. \& J. Harrigan (2008). 'Zeroes, Quality and Space: Trade Theory and Trade Evidence,' NBER Working Paper 13214, March.

Baldwin, R. \& P. Krugman (1989). 'Persistent trade effects of large exchange rate shocks,' The Quarterly Journal of Economics 104:4, pp 635-654.

Blanchard, O. \& J. Wolfers (2000). 'The Role of Shocks and Institutions in the Rise of European Unemployment: The Aggregate Evidence, 1999 Harry Johnson Lecture,' Economic Journal 100, C1-33.

Branco, F. (1994). 'Favouring Domestic Firms in Procurement Contracts,' Journal of International Economics 37: 65-80.

Brenton, P. (2001). 'What are the limits to economic integration?' Centre for European Policy Studies, Working Document No. 177, November.

Breton, A. \& P. Salmon (1995). 'Are Discriminatory Procurement Policies Motivated by Protectionism?' Kyklos 49: 47-68.

Brülhart M. \& F. Trionfetti (2001). 'Industrial Specialisation and Public Procurement: Theory and Empirical Evidence,' Journal of Economic Integration 16:1, 106-127.

Burguet, R. \& Y. Che (2004). 'Competitive Procurement with Corruption,' The RAND Journal of Economics 35(1): 50-68.

Burguet, R. \& M. Perry (2000). 'Bribery and Favouritism by Auctioneers in Sealed Bid Auctions,' Mimeo, Rutgers University \& Institut d'Analisi Economica (CSIC). 
Cameron, A.C. \& P.K. Trivedi (1986). 'Econometric models based on count data: Comparisons and applications of some estimators and tests,' Journal of Applied Econometrics, 1, 29-53.

Campa, J.M. (2004). 'Exchange rates and trade: How important is hysteresis in trade?' European Economic Review 48, 527-548.

Chen, X. (1995). 'Directing Government Procurement as an Incentive of Production,' Journal of Economic Integration 10: 130-40.

Compte, O., A. Lambert-Mogiliansky \& T. Verdier (2005). 'Corruption and Competition in Procurement Auctions,' The RAND Journal of Economics 36(1): 1-15.

Coviello, D. \& S. Gagliarducci (2010). 'Tenure in Office and Public Procurement,' mimeo.

Diermeier, D. \& A. Merlo (1999). 'A Structural Model of Government Formation,' Mimeo, Northwestern University.

Drazen, A. (2000). Political Economy in Macroeconomics, Princeton: Princeton University Press.

European Commission (1997). Single Market Review: Public Procurement. Kogan Page, London.

Evenett, S. J. \& B. Hoekman (2004). 'International disciplines on government procurement: A review of economic analyses and their implications,' mimeo.

Evenett, S. J. \& B. Hoekman (2005). 'Government Procurement: Market Access, Transparency, and Multilateral Trade Rules,' European Journal of Political Economy 21:1 pp 163-183.

Evenett, S.J. \& A. Shingal (2006). 'Monitoring Implementation: Japan and the WTO Agreement on Government Procurement,' in Economic Development \& Multilateral Trade Cooperation, The World Bank.

Evenett, S.J. (2009a). 'What can be learned from crisis-era protectionism? An initial assessment,' Business \& Politics, The Berkeley Electronic Press 11: 3 article 4.

Evenett, S.J. (2009b). 'The emerging contours of crisis-era protectionism,' in Broken promises: A G-20 summit, Second GTA Report, CEPR, London.

Fukuyama, F (1995). Trust: The Social Virtues and the Creation of Prosperity, Free Press, New York.

Goldman, E., J. Rocholl \& J. So (2009). 'Political Connections and the Allocation of Procurement Contracts,' Mimeo. 
Gourieroux, C., A. Montfort \& A. Trognon (1984). 'Pseudo maximum likelihood methods: Applications to Poisson models,' Econometrica, 52, 701-20.

Greene, W.H. (1994). 'Accounting for excess zeros and sample selection in Poisson and negative binomial models,' Stern School of Business, New York University, Working Paper 94-10.

Guimarães (2008). 'The Fixed-effects Negative Binomial Model Revisited,' Economics Letters 99:1, 63-66.

Hillberry, R. \& D. Hummels (2002). 'Explaining home bias in consumption: The role of intermediate input trade,' NBER Working Paper 9020.

Hoekman, B. \& P. Mavroidis (1997). Law and Policy in Public Purchasing: The WTO Agreement on Government Procurement, University of Michigan Press.

Hyytinen, A., S. Lundberg \& O. Toivanen (2009). 'Politics and Procurement: Evidence from Cleaning Contracts,' Mimeo.

IIDE (2009). Trade in Services Database, Institute for International \& Development Economics.

IMF (various years). International Financial Statistics.

Khorana S. and A. Shingal (2008). 'Barriers to Government Procurement in the European Union,' in Strategies and Preparedness for Trade and Globalization in India, UNCTAD (eds.), February.

Laffont, J.J. \& J. Tirole (1991).'Auction Design and Favouritism,' International Journal of Industrial Organization 9: 9-42.

Long, J.S. (1997). Regression Models for Categorical and Limited Dependent Variables, Sage, Thousand Oaks.

Long, J. S. \& J. Freese (2005). Regression Models for Categorical Outcomes Using Stata, Second Edition. College Station, TX: Stata Press.

Mastanduno, M. (1991). 'Do relative gains matter? America's response to Japanese industrial policy,' International Security 16: 73-113.

McAfee, R. P. \& J. McMillan (1989). 'Government Procurement and International Trade,' Journal of International Economics 26: 291-308.

Naegelen, F. \& M. Mougeot (1998). 'Discriminatory public procurement policy and cost reduction incentives,' Journal of Public Economics 67: 349-367. 
Nicita, A. and M. Olarreaga (2006). 'Trade, Production and Protection 1976-2004,' World Bank Economic Review 21(1).

OECD (2002). 'The Size of Government Procurement Markets,' available at www.oecd.org/dataoecd/34/14/1845927.pdf.

OECD (various years). STAN database, 'StatExtracts' (http://stats.oecd.org/Index.aspx)

OCED (various years). Trade in Services by Service Category database, 'StatExtracts' (http://stats.oecd.org/Index.aspx).

Persson, T. (2002). 'Do Political Institutions Shape Economic Policy?,' Econometrica 70(3): 883-905.

Persson, T. \& G. Tabellini (1990). Macroeconomic Policy, Credibility and Politics, London: Hardwood Academy Publishers.

Persson, T. \& G. Tabellini (2000). 'Political Institutions and Economic Policy Outcomes: What Are the Stylized Facts? Mimeo, Institute for International Economic Studies.

Rauch, J (1996). 'Networks versus Markets in International Trade,' Working Paper 5617, NBER, Cambridge, MA.

Ravn, M.O., S. Schmitt-Grohé \& M. Uribe (2008). 'Explaining the Effects of Government Spending Shocks on Consumption and the Real Exchange Rate,' Mimeo.

Rogoff, K. (1990). 'Equilibrium Political Budget Cycles,' American Economic Review 80: 2136.

Rogoff, K. \& A. Silbert (1988). 'Elections and macroeconomic political cycles,' Review of Economic Studies 55: 1-16.

Rose-Ackerman, S. (1975). 'The Economics of Corruption,' Journal of Public Economics 4: 187-203.

Rose-Ackerman, S. (1978). Corruption: A Study in Political Economy, New York: Academic Press.

Rothenberg, J. (1993). "Comment" in Jim Leitzel \& Jean Tirole eds. Incentives in Procurement Contracting, Boulder: Westview Press.

Santos Silva, J. M. C. and S. Tenreyro (2006). 'The log of gravity,' The Review of Economics and Statistics 88 (4): 641- 658.

Schooner S.L. \& C.R. Yukins (2009). 'Public procurement: Focus on people, value for money and systemic integrity, not protectionism,' in Richard Baldwin \& Simon Evenett eds. The 
collapse of global trade, murky protectionism, and the crisis: Recommendations for the G-20, VoxEU; available at http://www.voxeu.org/index.php?q=node/3199

Shi, M. \& J. Svensson (2000). 'Conditional Political Business Cycles: Theory and Evidence,' Mimeo, Institute for International Economic Studies.

Shingal, A. (2009). 'Three Essays on Trade in Services: Exploring tradability, regional trade and government procurement of services,' unpublished DPhil dissertation, University of Sussex.

Shingal, A. (2011). 'The WTO's Agreement on Government Procurement: Whither market access?' World Trade Review, 10:4, 1-23.

Tanzi, V., \& L. Schuknecht (2000). Public Spending in the $20^{\text {th }}$ Century: A Global Perspective, Cambridge, U.K.: Cambridge University Press.

Trionfetti, F. (2000). 'Discriminatory public procurement and international trade,' World Economy 23: 57-76.

UN Comtrade (various years).

UNIDO (2010). INDSTAT4 database.

UNSC (2002). 'GATS, CPC Version 1.1,' GNS/W/120.

(http://unstats.un.org/unsd/statcom/doc02/cpc.pdf)

UNSD (http://unstats.un.org/unsd/cr/registry/regso.asp?Ci=1\&Lg=1)

Vagstad, S. (1995). 'Promoting fair competition in public procurement,' Journal of Public Economics 58: 283-307.

Vuong, Q.H. (1989). 'Likelihood ratio tests for model selection and non-nested hypotheses,' Econometrica, 57, 307-33.

Weichenrieder, J.A. (2001). 'Public procurement in the presence of capital taxation,' Regional Science and Urban Economics 31: 339-353.

World Bank (various years). World Development Indicators.

World Trade Organization (various years). 'Statistics reports under Article XIX: 5 of the GPA,' Committee on Government Procurement.

(http://www.wto.org/english/tratop_e/gproc_e/gpstat_e.htm) 
Figure 1: Distribution of foreign procurement value (real USD mn)
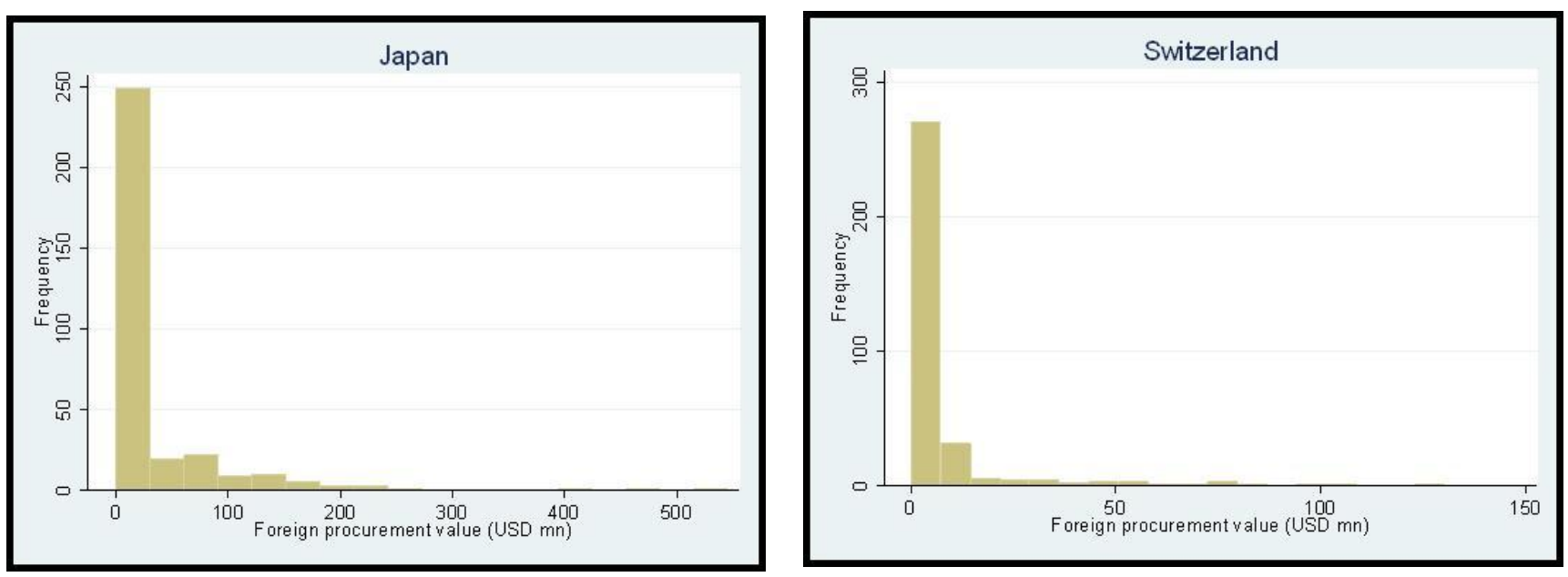

Figure 2: Comparison of residual plots in estimating foreign procurement of goods
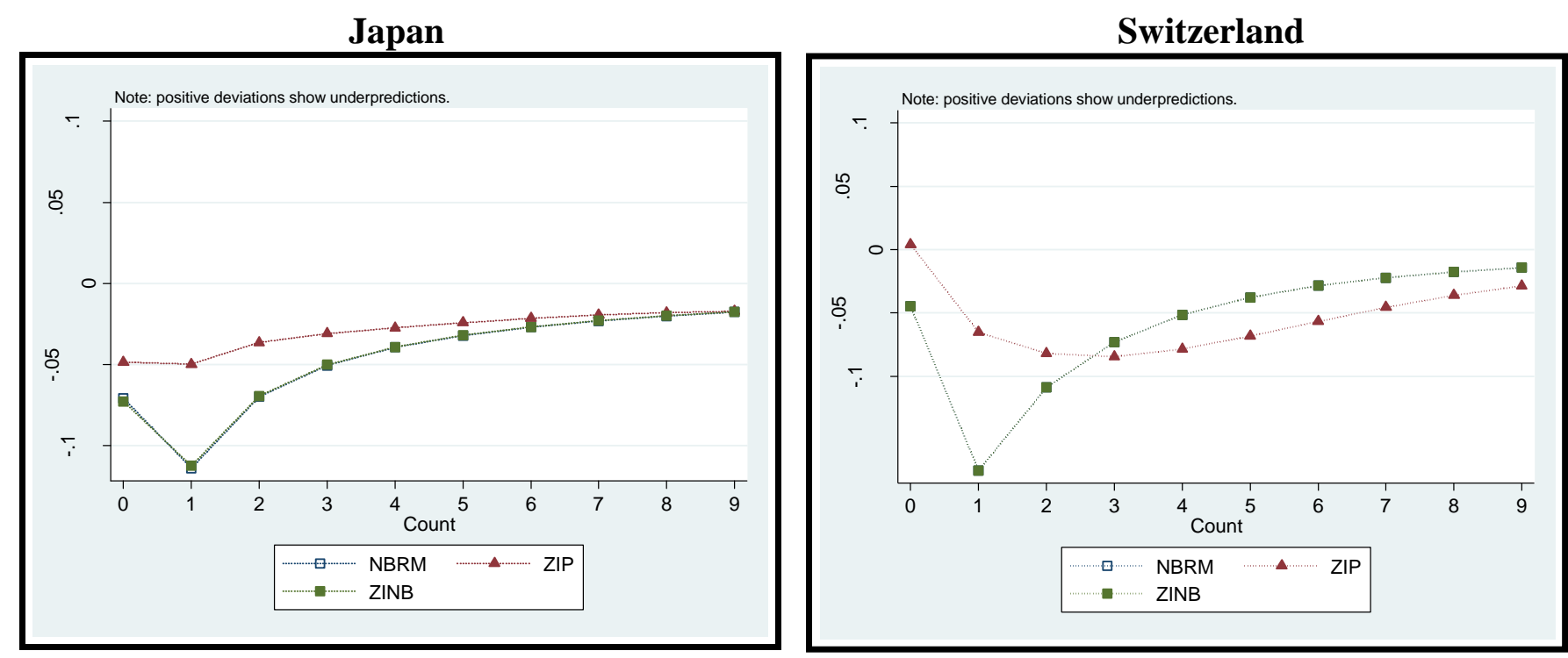

Note: (1) "NBRM" stands for the Negative Binomial Regression Model; "ZIP" stands for the Zero-inflated Poisson; "ZINB" stands for the Zero-inflated Negative Binomial 
Table 1: Evolution of sample variables over time

\begin{tabular}{|c|c|c|c|c|c|c|c|c|c|c|c|c|c|c|c|}
\hline \multicolumn{16}{|c|}{ JAPANESE PROCUREMENT OF GOODS } \\
\hline Year & 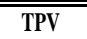 & ב ATV & FPV(\%) & "ATN & FPPN(\%) & 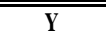 & "M_Prop (\%) & "X_Prop (\%) & $\overline{\mathrm{N}}$ & 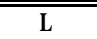 & 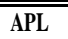 & 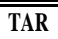 & "ROG & " UNEMP & "REER \\
\hline 1990 & 7194 & 2953.0 & 13.8 & 7081 & 27.8 & 1575292.7 & 6.8 & 13.7 & 371556 & 12455507 & 0.126 & 2.41 & 5.2 & 2.1 & 75.0 \\
\hline 1991 & 8095 & 3598.7 & 14.8 & 8072 & 24.7 & 1849721.4 & 6.4 & 13.4 & 388619 & 12685728 & 0.146 & 2.29 & 3.4 & 2 & 80.8 \\
\hline 1992 & 8143 & 3713.1 & 14.9 & 7424 & 27.4 & 2005705.4 & 5.9 & 14.0 & 374488 & 12709965 & 0.158 & 2.24 & 1 & 2.2 & 83.4 \\
\hline 1993 & 8941 & 4488.7 & 20.8 & 9060 & 28.9 & 2168615.0 & 6.3 & 14.2 & 372382 & 12135989 & 0.179 & 2.24 & 0.2 & 2.5 & 98.4 \\
\hline 1997 & 45485 & 6045.6 & 14.9 & 9206 & 28.0 & 1952595.8 & 10.6 & 18.3 & 247372 & 7548248 & 0.259 & 1.74 & 1.6 & 3.4 & 83.6 \\
\hline 1998 & 88360 & 12698.9 & 14.0 & 10062 & 25.3 & 1726083.8 & 12.5 & 23.2 & 256891 & 7421873 & 0.233 & 1.53 & -2 & 4.1 & 82.2 \\
\hline 1999 & 49745 & 6257.0 & 12.7 & 8396 & 22.3 & 1917741.1 & 12.6 & 22.5 & 237509 & 7098685 & 0.270 & 1.47 & -0.1 & 4.7 & 93.0 \\
\hline 2000 & 44137 & 5438.6 & 16.5 & 8242 & 23.7 & 2134796.7 & 11.6 & 20.2 & 233480 & 6951040 & 0.307 & 1.37 & 2.9 & 4.8 & 100.0 \\
\hline 2001 & 41291 & 5268.6 & 12.1 & 7629 & 22.6 & 1885233.7 & 12.1 & 19.0 & 216167 & 6461663 & 0.292 & 1.47 & 0.2 & 5 & 89.5 \\
\hline 2002 & 47749 & 4980.9 & 15.5 & 8127 & 23.8 & 1738423.3 & 14.6 & 24.4 & 199669 & 6101126 & 0.285 & 1.47 & 0.3 & 5.4 & 82.9 \\
\hline 2003 & 54991.1 & 5913.8 & 11.4 & 7129 & 22.4 & 1959497.4 & 15.3 & 25.9 & na & 5973331 & 0.328 & 2.42 & 1.4 & 5.2 & 81.4 \\
\hline \multicolumn{16}{|c|}{ JAPANESE PROCUREMENT OF SERVICES } \\
\hline Year & TPV & ATV & FPV(\%) & ATN & FPN(\%) & YY & M_Prop (\%) & X_Prop (\%) & $\mathbf{N}$ & $\overline{\mathrm{L}}$ & APL & TAR & R0G & UNEMP & REER \\
\hline 1997 & 45485 & 26521.7 & 0.6 & 36147 & 0.2 & 2022220.2 & 3.4 & 2.6 & na & 17906478 & 0.113 & & 1.6 & 3.4 & 83.6 \\
\hline 1998 & 88360 & 26657.9 & 1.2 & 10365 & 0.7 & 2252842.9 & 2.8 & 2.1 & na & 17618138 & 0.128 & & -2 & 4.1 & 82.2 \\
\hline 1999 & 49745 & 15997.2 & 0.7 & 17639 & 0.4 & 2574553.7 & 2.4 & 1.8 & na & 17407620 & 0.148 & & -0.1 & 4.7 & 93.0 \\
\hline 2000 & 44137 & 13907.2 & 0.8 & 14645 & 0.5 & 2415380.4 & 2.7 & 2.1 & na & 17559240 & 0.138 & & 2.9 & 4.8 & 100.0 \\
\hline 2001 & 41291 & 16049.0 & 0.8 & 17801 & 0.5 & 2122614.8 & 3.0 & 2.3 & na & 17528041 & 0.121 & & 0.2 & 5 & 89.5 \\
\hline 2002 & 47749 & 19286.7 & 0.7 & 21571 & 0.5 & 2323294.6 & 2.7 & 2.1 & na & 17331294 & 0.134 & & 0.3 & 5.4 & 82.9 \\
\hline 2003 & 54991.1 & 11202.9 & 1.0 & 2618 & 3.3 & 2639735.7 & 2.5 & 2.0 & na & 17373377 & 0.152 & & 1.4 & 5.2 & 81.4 \\
\hline \multicolumn{16}{|c|}{ SWISS PROCUREMENT OF GOODS } \\
\hline Year & TPV & ATV & FPV(\%) & ATN & FPN(\%) & $\overline{\mathrm{Y}}$ & M_Prop (\%) & X_Prop (\%) & $\overline{\mathrm{N}}$ & $\overline{\mathrm{L}}$ & APL & TAR & ROG & UNEMP & REER \\
\hline 1990 & 642.5 & 274.5 & 76.0 & 368 & 69.6 & 130443.9 & 40.1 & 39.0 & na & 1147900 & 0.114 & 0.0 & 3.8 & 0.5 & 100.2 \\
\hline 1991 & 720.6 & 293.5 & 66.0 & 428 & 61.2 & 131137.5 & 38.7 & 38.4 & na & 716602 & 0.183 & 0.0 & -0.9 & 1.7 & 102.2 \\
\hline 1993 & 652.5 & 231.7 & 70.0 & 486 & 74.9 & 130167.8 & 37.1 & 41.2 & na & 645064 & 0.202 & 0.0 & -0.2 & 3.7 & 102.7 \\
\hline 1994 & 690.3 & 278.6 & 69.0 & 368 & 65.8 & 147454.7 & 37.1 & 40.8 & na & 636931 & 0.232 & 0.0 & 1.2 & 3.8 & 107.4 \\
\hline 1995 & 676.3 & 222.0 & 59.3 & 292 & 63.0 & 177647.2 & 37.3 & 40.2 & na & 640642 & 0.277 & 0.0 & 0.4 & 3.3 & 114.4 \\
\hline 1996 & 1404.5 & 184.0 & 56.0 & 287 & 61.7 & 170542.7 & 34.8 & 37.7 & na & 621350 & 0.274 & 0.0 & 0.6 & 3.7 & 111.3 \\
\hline 1997 & 1856.3 & 283.3 & 25.5 & 424 & 53.3 & 148625.3 & 42.6 & 46.0 & 17905 & 439963 & 0.338 & 0.0 & 2.1 & 4.1 & 102.9 \\
\hline 1998 & 1551.5 & 228.8 & 56.1 & 327 & 54.1 & 97334.7 & 73.8 & 76.9 & 17440 & 367999 & 0.264 & 0.0 & 2.6 & 3.6 & 104.2 \\
\hline 1999 & 1517.7 & 322.3 & 44.3 & 323 & 48.3 & 83580.5 & 78.9 & 83.5 & 16975 & 433966 & 0.193 & 0.0 & 1.3 & 3.1 & 102.3 \\
\hline 2000 & 1744.5 & 272.7 & 36.1 & 461 & 30.8 & 84574.2 & 88.2 & 91.4 & 17366 & 445409 & 0.190 & 0.0 & 3.6 & 2.6 & 100 \\
\hline 2001 & 1898.2 & 299.3 & 42.9 & 417 & 35.3 & 85198.6 & 89.0 & 92.8 & 16168 & 448889 & 0.190 & 0.0 & 1.2 & 2.5 & 103.1 \\
\hline 2002 & 1815.1 & 168.3 & 53.6 & 845 & 69.7 & 101399.2 & 82.9 & 93.1 & 11036 & 435998 & 0.233 & 0.0 & 0.4 & 2.9 & 106.8 \\
\hline 2003 & 2200.7 & 256.3 & 51.5 & 1026 & 67.0 & 114269.8 & 83.7 & 94.0 & na & 411384 & 0.278 & 0.0 & -0.2 & 4.1 & 106.4 \\
\hline \multicolumn{16}{|c|}{ SWISS PROCUREMENT OF SERVICES } \\
\hline Year & $\begin{array}{l}\text { TPV } \\
\end{array}$ & 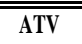 & FPV(\%) & 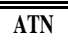 & FPN(\%) & $\overline{\mathrm{YY}}$ & "M_Prop (\%) & "X_Prop (\%) & $\overline{\mathrm{N}}$ & 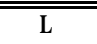 & 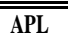 & $\begin{array}{l}\text { TAR } \\
\end{array}$ & ROG & 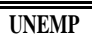 & "REER \\
\hline 1996 & 1404.5 & 211.4 & 9.4 & 194 & 8.8 & na & na & na & na & 1084114 & na & & 0.6 & 3.7 & 111.3 \\
\hline 1997 & 1856.3 & 255.4 & 4.2 & 320 & 5.9 & 160497.8 & 2.4 & 9.3 & na & 1082364 & 0.148 & & 2.1 & 4.1 & 102.9 \\
\hline 1998 & 1551.5 & 488.5 & 8.2 & 455 & 4.8 & 179963.6 & 2.7 & 9.3 & na & 1092921 & 0.165 & & 2.6 & 3.6 & 104.2 \\
\hline 1999 & 1517.7 & 305.8 & 4.3 & 284 & 8.5 & 160936.4 & 3.1 & 11.6 & na & 1113723 & 0.145 & & 1.3 & 3.1 & 102.3 \\
\hline 2000 & 1744.5 & 318.7 & 3.1 & 302 & 6.0 & 169765.2 & 3.2 & 11.8 & na & 1146172 & 0.148 & & 3.6 & 2.6 & 100 \\
\hline 2001 & 1898.2 & 478.0 & 4.8 & 327 & 6.1 & 170603.2 & 3.0 & 10.8 & na & 1200572 & 0.142 & & 1.2 & 2.5 & 103.1 \\
\hline 2002 & 1815.1 & 347.6 & 2.6 & 379 & 3.2 & 218742.2 & 2.0 & 8.7 & na & 1221333 & 0.179 & & 0.4 & 2.9 & 106.8 \\
\hline 2003 & 2200.7 & 517.6 & 25.4 & 447 & 23.9 & 250445.9 & 1.9 & 9.1 & na & 1215538 & 0.206 & & -0.2 & 4.1 & 106.4 \\
\hline
\end{tabular}

Source: WTO (various years); World Bank, World Development Indicators (various years); Nicita \& Olarreaga (2006); OECD STAN (various years); OECD Trade in Services (various years); UNIDO (2010); own calculations

Note: (1) "TPV" stands for total procurement value; "ATV" stands for above-threshold procurement by value of contracts; "FPV" stands for share of foreign procurement in AT procurement by value of contracts; "ATN" stands for above-threshold procurement by number of contracts; "FPN" stands for share of foreign procurement in AT procurement by number of contracts; "M_Prop" denotes the share of private sector imports in output; "X_Prop" denotes the share of private sector exports in output; rest of the variables are as defined in Table 1 (2) TPV, ATV, Y and APL are reported in USD mn (3) There are no data on services procurement before 1996 as the coverage of services in the GPA only began with the Uruguay Round. 
Table 2: Estimating Japanese foreign procurement value

\begin{tabular}{|c|c|c|c|c|c|c|c|c|c|c|c|c|}
\hline Explanatory variables & I & II & III & IV & $\mathbf{V}$ & VI & VII & VIII & IX & $\mathbf{X}$ & XI & XII \\
\hline Relative demand & $7.0^{* *}$ & $7.1 * *$ & 0.98 & $5.6^{* *}$ & 17.6 & 19.1 & $8.2^{* *}$ & $11.2 * * *$ & $5.3^{* * *}$ & $6.6^{* * *}$ & $3.6^{* * *}$ & $7.8^{* * *}$ \\
\hline Productivity & $2.9 * * *$ & $3.3^{* * *}$ & 1.7 & $9.03^{* * *}$ & $-5.9 * * *$ & $-5.5^{* * *}$ & 2.1 & -2.4 & $-29.3^{* * *}$ & $-28.2 * * *$ & $45.7 * * *$ & $-36.9 * * *$ \\
\hline Exports & 0.00 & 0.00 & 0.00 & 0.00 & $-.00002 * * *$ & $-.000023^{* * *} *$ & 0.00 & $-.00003^{* * *}$ & $-.0005^{* * *}$ & $-.00024 * *$ & $.00025^{* *}$ & $-.00025^{* *}$ \\
\hline \# Export destinations & $-.007 * * *$ & $-.007 * * *$ & $.018^{* *}$ & 0.00 & 0.00 & 0.00 & $.047 * * *$ & $.0078^{* * *}$ & -0.03 & $-1.29 * * *$ & -0.12 & -0.01 \\
\hline Number of firms & & & & & $-.000022^{*}$ & 0.00 & 0.00 & 0.00 & & & & \\
\hline Tariffs & & & & & $-.51 * * *$ & $-.51 * * *$ & -0.29 & $-.59 * * *$ & & & & \\
\hline Imports & 0.00 & 0.00 & $.0001^{* * * *}$ & 0.00 & $.00016^{* * *}$ & $.00015^{* * *}$ & $.00017 * * *$ & $.0002 * * *$ & $.00017^{*}$ & 0.00 & 0.00 & 0.00 \\
\hline Rate of growth & $-.15^{*}$ & & & & -0.04 & & & & -0.15 & & & \\
\hline Exchange rate & 0.01 & & & & 0.02 & & & & -0.02 & & & \\
\hline Election year & -0.13 & & & & -0.14 & & & & $1.4^{*}$ & & & \\
\hline Election year (-1) & -0.23 & & & & -0.26 & & & & 0.73 & & & \\
\hline URGPA & 0.12 & & & & 0.04 & & & & & & & \\
\hline Constant & $3.23^{* *}$ & $3.01^{* * *}$ & $-8.62 * * *$ & -1.50 & 1.41 & $2.4 * * *$ & $-12.62^{* *}$ & -0.04 & $11.25^{* * *}$ & $69.0^{* * *}$ & 2.12 & -23.06 \\
\hline \# observations & 281 & 281 & 281 & 281 & 180 & 180 & 180 & 180 & 35 & 35 & 35 & 35 \\
\hline df_m & 10 & 15 & 43 & 26 & 12 & 16 & 35 & 26 & 9 & 11 & 15 & 18 \\
\hline Year fixed effects & No & Yes & Yes & Yes & No & Yes & Yes & Yes & No & Yes & Yes & Yes \\
\hline Time-invariant SSFE & No & No & Yes & No & No & No & Yes & No & No & No & Yes & No \\
\hline Trend-varying SSFE & No & No & No & Yes & No & No & No & Yes & No & No & No & Yes \\
\hline Over-dispersion parameter (alpha) & $3.67 * * *$ & $3.67^{* * * *}$ & $0.51^{* * *}$ & $3.1^{* * *}$ & $2.6^{* * *}$ & $2.56^{* * *}$ & $0.59 * * *$ & $1.93^{* * *}$ & 1.12 & 0.76 & 0.00 & $0.00^{* * *}$ \\
\hline
\end{tabular}

Note: (1) Legend: * $\mathrm{p}<.1 ; * * \mathrm{p}<.05 ; * * * \mathrm{p}<.01 \quad$ (2) Table reports robust estimates

Table 3: Estimating Swiss foreign procurement value

\begin{tabular}{|c|c|c|c|c|c|c|c|c|c|c|c|}
\hline Explanatory variables & I & II & III & IV & $\mathbf{V}$ & VI & VII & VIII & IX & $\mathbf{X}$ & XI \\
\hline Relative demand & $20.0 * * *$ & $20.2 * * *$ & $7.3^{* * *}$ & $21.86^{* * *}$ & $30.58 * * *$ & $29.95 * * *$ & $10.14 * * *$ & $29.6 * * *$ & $18.16^{* * *}$ & $19.8^{* * *}$ & $-19.9 * *$ \\
\hline Productivity & $5.4 * * *$ & $6.5^{* * *}$ & $-3.3 * *$ & $4.4 * * *$ & 2.46 & $3.26 *$ & $-5.4 * *$ & 1.33 & $-16.7^{* *}$ & -33.47 & $-163.9^{* *}$ \\
\hline Exports & $.00006 * *$ & $.00006^{* *}$ & 0.00 & $.00009 * * *$ & $.00008 * * *$ & $.00008 * * *$ & 0.00 & $.0001 * * *$ & 0.00 & 0.00 & 0.00 \\
\hline \# Export destinations & $.004 * * *$ & $.004 * * *$ & $.02 * *$ & 0.00 & $.003^{* *}$ & $.003 * *$ & $.02 * *$ & 0.00 & $-.05^{* *}$ & $.4 * * *$ & 0.66 \\
\hline Imports & $.0002 * * *$ & $.0002 * *$ & $-.0004 * *$ & $.0001^{*}$ & 0.00 & 0.00 & $-.0005^{* *}$ & 0.00 & 0.00 & 0.00 & 0.00 \\
\hline Rate of growth & -0.08 & & & & -0.10 & & & & $-.74 * *$ & & \\
\hline Exchange rate & $-.13^{* * *}$ & & & & $-.083^{* *}$ & & & & $-.59 * * *$ & & \\
\hline Election year & 0.45 & & & & 0.30 & & & & -0.53 & & \\
\hline Election year (-1) & $.50 * *$ & & & & 0.42 & & & & $3.36^{* * *}$ & & \\
\hline URGPA & 0.36 & & & & $.71 * *$ & & & & & & \\
\hline Constant & $9.9 * *$ & $-2.02 * * *$ & -2.22 & -1.12 & 6.69 & -1.04 & -1.41 & -0.04 & $62.2 * * *$ & $-7.14 * * *$ & 13.90 \\
\hline \# observations & 156 & 156 & 156 & 156 & 130 & 130 & 130 & 130 & 26 & 26 & 26 \\
\hline df_m & 10 & 17 & 33 & 30 & 10 & 17 & 29 & 30 & 9 & 10 & 13 \\
\hline Year fixed effects & No & Yes & Yes & Yes & No & Yes & Yes & Yes & No & Yes & Yes \\
\hline Time-invariant SSFE & No & No & Yes & No & No & No & Yes & No & No & No & Yes \\
\hline Trend-varying SSFE & No & No & No & Yes & No & No & No & Yes & No & No & No \\
\hline Over-dispersion parameter (alpha) & $1.34 *$ & 1.23 & $0.32 * *$ & 1.07 & 1.19 & 1.04 & $0.34 * * *$ & 0.75 & $0.0 * * *$ & $0.0^{* * *}$ & $0.0^{* * *}$ \\
\hline
\end{tabular}

Note: (1) Legend: * $p<.1 ; * * p<.05 ; * * * p<.01 \quad$ (2) Table reports robust estimates

(3) Convergence was not attained in the services estimation with trend-varying SSFE, hence column XII is absent in the table 
Table 4: Estimating Japanese import demand for contracts

\begin{tabular}{|c|c|c|c|c|c|c|c|c|c|c|c|c|}
\hline Explanatory variables & I & II & III & IV & $\mathbf{V}$ & VI & VII & VIII & IX & $\mathbf{X}$ & XI & XII \\
\hline Relative demand & $12.8^{* * *}$ & $12.7^{* * *}$ & $2.65^{* * *}$ & $11.6^{* *}$ & $28.8^{* * *}$ & $29.5^{* * *}$ & $7.47 * * *$ & $24.6^{* * *}$ & $-4.1881965^{*}$ & -4.1 & 1.8 & $6.4^{* * *}$ \\
\hline Average contract size (domestic) & -0.2 & -0.2 & $.05^{*}$ & -0.2 & 0.1 & $.23^{*}$ & 0.0 & 0.0 & -0.1 & -0.2 & $.065^{* *}$ & $.2^{* *}$ \\
\hline Average contract size (foreign) & $-.25^{* *}$ & $-.28 * * *$ & 0.0 & $-.24 * *$ & $-.14^{* *}$ & $-.14^{* *}$ & 0.0 & 0.0 & $.22 * * *$ & $.20 * *$ & 0.0 & $-.21 *$ \\
\hline Productivity & $2.9^{* * * *}$ & $2.96 * * *$ & -0.7 & $9.2 * * *$ & $-5.7 * * *$ & $-6.1 * * *$ & $-3.6^{* *}$ & -1.3 & $-23.0^{* * *}$ & $-23.9 * * *$ & $14.9 * * *$ & $-13.0 * * *$ \\
\hline Exports & 0.0 & 0.0 & 0.0 & $-.00002 * *$ & 0.0 & 0.0 & 0.0 & $-.000016^{* * *}$ & $-.0007 * * *$ & $-.0007 * * *$ & 0.0 & $-.00066^{* * *}$ \\
\hline \# Export destinations & 0.0 & 0.0 & $.016^{* * *}$ & 0.0 & 0.0 & 0.0 & $.019^{* * *}$ & $.007 * * *$ & 0.0 & -0.1 & 0.0 & 0.1 \\
\hline Number of firms & & & & & $-.00003 * * *$ & $-.00003^{* * *}$ & $.000025^{* * *}$ & $-.000013^{* *}$ & & & & \\
\hline Tariffs & & & & & $-.24 * * *$ & $-.25^{* * *}$ & $.30^{*}$ & $-.35^{* * *}$ & & & & \\
\hline Imports & $-.00007^{* *}$ & $-.00007 * *$ & $.00007 * * *$ & 0.0 & $.00009^{* *}$ & $.0001^{* *}$ & $.00006^{* *}$ & $.00018^{* * *}$ & $.0004 * *$ & $.0004^{* *}$ & 0.0 & $.00045^{* * *}$ \\
\hline Rate of growth & -0.06 & & & & -0.03 & & & & -0.04 & & & \\
\hline Exchange rate & 0.00 & & & & 0.02 & & & & -0.02 & & & \\
\hline Election year & -0.18 & & & & -0.17 & & & & 1.33 & & & \\
\hline Election year (-1) & -0.32 & & & & -0.26 & & & & 0.83 & & & \\
\hline URGPA & $.81^{* *}$ & & & & $.60^{* *}$ & & & & & & & \\
\hline Constant & $3.4 * *$ & $3.4 * * *$ & $-4.6 * * *$ & 0.9 & 1.2 & $2.1 * * *$ & $-9.8^{* * *}$ & -0.4 & $7.4 * * *$ & 13.6 & -0.1 & -12.5 \\
\hline \# observations & 214 & 214 & 214 & 214 & 127 & 127 & 127 & 127 & 29 & 29 & 29 & 29 \\
\hline df_m & 12 & 17 & 45 & 28 & 14 & 18 & 37 & 28 & 11 & 13 & 17 & 20 \\
\hline Year fixed effects & No & Yes & Yes & Yes & No & Yes & Yes & Yes & No & Yes & Yes & Yes \\
\hline Time-invariant SSFE & No & No & Yes & No & No & No & Yes & No & No & No & Yes & No \\
\hline Trend-varying SSFE & No & No & No & Yes & No & No & No & Yes & No & No & No & Yes \\
\hline Over-dispersion parameter (alpha) & $2.1 * * *$ & $2.1 * * *$ & $0.07 * * *$ & $1.9 * * *$ & 0.9 & 0.8 & $0.0^{* * *}$ & $0.4 * * *$ & 0.1 & $0.0^{* * * *}$ & $0.0^{* * *}$ & $0.0^{* * *}$ \\
\hline
\end{tabular}

Note: (1) Legend: * $p<.1 ; * * p<.05 ; * * * p<.01$

(2) Table reports robust estimates

Table 5: Estimating Swiss import demand for contracts

\begin{tabular}{|c|c|c|c|c|c|c|c|c|c|c|c|}
\hline Explanatory variables & I & II & III & IV & $\mathbf{V}$ & VI & VII & VIII & $\mathbf{X}$ & XI & XII \\
\hline Relative demand & $8.4 * * *$ & $8.7 * * *$ & $3.6^{* *}$ & $8.0 * * *$ & $18.1^{* * * *}$ & $17.5^{* * * *}$ & $4.7 * * *$ & $17.2 * * *$ & $-5.3 * * *$ & $-9.4 * * *$ & $-5.3 * * *$ \\
\hline Average contract size (domestic) & -0.12 & -0.20 & -0.07 & -0.25 & -0.21 & -0.24 & -0.07 & -0.62 & $-.94 * * *$ & $-.41 * * *$ & $-.94 * * *$ \\
\hline Average contract size (foreign) & $-.51 * * *$ & $-.51^{* * *}$ & $-.29 * * *$ & $-.62 * * *$ & $-.80^{* * *}$ & $-.82 * * *$ & -0.21 & $-.72 * * *$ & $1.4^{* * *}$ & $-.12 * * *$ & $1.4^{* * *}$ \\
\hline Productivity & $6.3 * * *$ & $6.6 * * *$ & $-3.1 * *$ & $7.5^{* * * *}$ & $3.0 * * *$ & $3.4 * * *$ & $-7.4 * *$ & $3.6^{* * * *}$ & $-411.2 * * *$ & $-2.1 * * *$ & $-411.2 * * *$ \\
\hline Exports & 0.00 & 0.00 & $.0001 * *$ & 0.00 & 0.00 & 0.00 & $.0002 * * *$ & 0.00 & $.009 * * *$ & $-.003^{* * *}$ & $.009 * * *$ \\
\hline \# Export destinations & $.0024 * *$ & $.0027 * *$ & $.018 * * *$ & 0.00 & $.0023^{* *}$ & $.002 *$ & $.024 *$ & $.002 *$ & $.95^{* * *}$ & $.18^{* * *}$ & $.95^{* * *}$ \\
\hline Imports & $.0002 * * *$ & $.0002 * * *$ & $-.0005^{* * *}$ & $.00024 * * *$ & 0.00 & 0.00 & $-.0006 * * *$ & 0.00 & $-.01 * * *$ & $-.004 * * *$ & $-.01 * * *$ \\
\hline Rate of growth & -0.02 & & & & -0.07 & & & & & & \\
\hline Exchange rate & $-.12 * * *$ & & & & $-.08 * * *$ & & & & & & \\
\hline Election year & 0.17 & & & & 0.06 & & & & & & \\
\hline Election year (-1) & 0.28 & & & & 0.16 & & & & & & \\
\hline URGPA & $.86^{* * * *}$ & & & & $1.25 * * *$ & & & & & & \\
\hline Constant & $10.7 * * *$ & -0.57 & -0.04 & -1.80 & $8.2^{* * *}$ & 0.01 & -1.09 & -0.41 & $30.5 * * *$ & $25.8^{* * * *}$ & $30.5^{* * *}$ \\
\hline \# observations & 97 & 97 & 97 & 97 & 84 & 84 & 84 & 84 & 13 & 13 & 13 \\
\hline df_m & 12 & 19 & 32 & 32 & 12 & 19 & 29 & 32 & 11 & 7 & 2 \\
\hline Year fixed effects & No & Yes & Yes & Yes & No & Yes & Yes & Yes & Yes & Yes & Yes \\
\hline Time-invariant SSFE & No & No & Yes & No & No & No & Yes & No & No & Yes & No \\
\hline Trend-varying SSFE & No & No & No & Yes & No & No & No & Yes & No & No & Yes \\
\hline Over-dispersion parameter (alpha) & $1.55^{* * *}$ & $0.60 * * *$ & $0.06 * * *$ & $0.54 * * *$ & $0.51 * * *$ & $0.46^{* * *}$ & 0.02 & $0.37 * * *$ & $0.0^{* * *}$ & $0.0^{* * *}$ & $0.0^{* * *}$ \\
\hline
\end{tabular}

Note: (1) Legend: * $\mathrm{p}<.1 ; * * \mathrm{p}<.05 ; * * * \mathrm{p}<.01 \quad$ (2) Table reports robust estimates

(3) Convergence was not attained in the services estimation in the baseline specification, hence column IX is absent in the table 
Table A1: Tests \& fit statistics from Countfit

\begin{tabular}{|c|c|c|c|c|c|c|c|c|c|c|c|c|c|c|c|}
\hline \multicolumn{7}{|c|}{ Primary estimation for goods (Japan) } & \multicolumn{9}{|c|}{ Primary estimation for goods (Switzerland) } \\
\hline NBRM & & $\mathrm{BIC}=149.987$ & $\mathrm{AIC}=\mathbf{5 . 7 7 8}$ & Prefer & Over & Evidence & NBRM & & $\mathrm{BIC}=$ & 39.664 & $\mathrm{AIC}=$ & 4.908 & Prefer & Over & Evidence \\
\hline \multirow[t]{2}{*}{ vs } & ZIP & $\mathrm{BIC}=2121.316$ & $\mathrm{dif}=-1971.330$ & NBRM & ZIP & Very strong & vs & ZIP & $\mathrm{BIC}=$ & 454.912 & $\mathrm{dif}=$ & -415.248 & NBRM & ZIP & Very strong \\
\hline & & $\mathrm{AIC}=16.712$ & $\mathrm{dif}=-10.934$ & NBRM & ZIP & & & & $\mathrm{AIC}=$ & 8.08 & dif $=$ & -3.172 & NBRM & ZIP & \\
\hline \multirow[t]{3}{*}{ vs } & ZINB & $\mathrm{BIC}=159.800$ & $\mathrm{dif}=-9.814$ & NBRM & ZINB & Strong & vs & ZINB & $\mathrm{BIC}=$ & 49.399 & dif $=$ & -9.735 & NBRM & ZINB & Strong \\
\hline & & $\mathrm{AIC}=5.797$ & $\mathrm{dif}=-0.019$ & NBRM & IINB & & & & $\mathrm{AIC}=$ & 4.939 & dif $=$ & -0.031 & NBRM & ZINB & \\
\hline & & Vuong $=1.856$ & prob $=0.032$ & ZINB & NBRM & $p=0.032$ & & & Vuong $=$ & $=-6.842$ & prob $=$ & 0 & NBRM & ZINB & $p=0.000$ \\
\hline ZIP & & $\mathrm{BIC}=2121.316$ & $\mathrm{AIC}=16.712$ & Prefer & Over & Evidence & ZIP & & $\mathrm{BIC}=$ & 454.912 & AIC $=$ & 8.08 & Prefer & Over & Evidence \\
\hline \multirow[t]{3}{*}{ VS } & ZINB & $\mathrm{BIC}=159.800$ & $\mathrm{dif}=1961.516$ & ZINB & ZIP & Very strong & vS & ZINB & $\mathrm{BIC}=$ & 49.399 & dif $=$ & 405.513 & ZINB & ZIP & Very strong \\
\hline & & $\mathrm{AIC}=5.797$ & $\mathrm{dif}=10.915$ & ZINB & ZIP & & & & $\mathrm{AIC}=$ & 4.939 & dif $=$ & 3.141 & ZINB & ZIP & \\
\hline & & $L R X 2=1966.709$ & prob $=0.000$ & ZINB & ZIP & $p=0.000$ & & & LRX2 $=$ & 410.381 & prob $=$ & 0 & ZINB & ZIP & $p=0.000$ \\
\hline
\end{tabular}

Note: (1) "NBRM" stands for the Negative Binomial Regression Model; "ZIP" stands for the Zero-inflated Poisson; "ZINB" stands for the Zero-inflated Negative Binomial (2) "AIC" stands for the Akaike Information Criterion; "BIC" stands for the Bayesian Information Criterion; "Vuong" stands for the Vuong test statistic (Vuong, 1989) that tests for "excess zeroes" in the raw data; "LRX2" stands for the Likelihood Ratio Test. 


\section{Table A2: Goods and services procured by the Japanese and Swiss governments}

Goods (Japan \& Switzerland): (1) Products from agriculture, and from agricultural and food processing industries (2) Mineral products (3) Products of the chemical and allied industries (4) Medicinal and pharmaceutical products (5) Artificial resins and plastic materials, cellulose esters and ethers, and articles thereof: rubber, synthetic rubber, factice, and articles thereof; raw hides and skins, leather, fur skins and articles thereof, other than articles of apparel and clothing accessories of leather, saddlery and harness, articles of animal gut (6) Wood and articles of wood; wood charcoal, cork and articles of cork; paper making material; paper and paperboard and articles thereof: manufactures of straw of esparto and of other planting materials, basketwork and wickerwork (7) Textiles and textile articles, footwear, headgear umbrellas; sunshades; walking sticks, whips, riding crops and parts thereof: travel goods; hand-bags and similar containers; articles of apparel and clothing accessories, of leather or composition leather (8) Articles of stone, plaster, asbestos, mica and similar materials; ceramic products, other than sanitary fixtures; glass and glassware, other than illuminating and signalling glassware and optical elements of glass, not optically worked nor of optical glass (9) Iron and steel and articles thereof, other than boilers and radiators for central heating, air heaters and hot air distributors not electrically heated (10) Non-ferrous metals and articles, other than lamp and lighting fittings (11) Power generating machinery and equipment (12) Machinery specialized for particular industries (13) General industrial machinery and equipment, and machine parts (14) Office machines and automatic data processing equipment (15) Telecommunications and sound recording and reproducing apparatus and equipment (16) Electrical machinery, apparatus and appliances, and electrical parts thereof (17) Road vehicles (18) Railway vehicles and associated equipment (19) Aircraft and associated equipment (20) Ships boats and floating structures (21) Sanitary, plumbing, heating and lighting equipment (22) Medical, dental, surgical and veterinary equipment (23) Furniture and parts thereof (24) Professional, scientific and controlling instruments and apparatus (25) Photographic apparatus, equipment and optical goods; watches and clocks (26) Miscellaneous articles

Services (Japan): (41) Construction work (42) Architectural, engineering and other technical (51) Maintenance and repair of motor vehicles (52) Maintenance and repair of motorcycles and snowmobiles (53) Other land transport (54) Rental of sea-going vessels with operator (55) Rental of non-sea-going vessels with operator (56) Air transport (57) Freight transport agency (58) Courier (61) Electronic mail (62) Voice mail (63) On-line information and database retrieval (64) Electronic data interchange (65) Enhanced facsimile (66) Code and protocol conversion (67) On-line information and/or data processing (71) Computer and related (72) Market research and public opinion polling (73) Advertising (74) Armoured car (75) Building-cleaning (76) Publishing and printing (77) Repair incidental to metal products, machinery and equipment (78) Sewage and refuse disposal, sanitation and other environmental protection services

Services (Switzerland): (1) Discussion to the wide direction (discussion, inspection, repairs) (2) Land transportation, including transportation of money and mail, except postal traffic and rail transportation (3) Air transportation, transportation of travellers and of merchandise, except transportation of courier (4) Transportation of mail by land or by airplane (except rail transportation) (5) Telecommunications (except vocal telephony, telex, radio telephony, radio-messaging and telecommunications by satellite) (6) Assurance and bank, except financial services relating to the transmission, sale, purchase or transfer of titles or of other financial instruments, as well as services furnished by central banks (7) Computer and related (8) Accounting, auditing and book-keeping (9) Market and public-opinion polling (10) Management consulting and related (11) Architecture, urban installation and environmental architecture (12) Consulting and technical, technical integrated, relevant scientific and technical consulting, technical essays and analyses of construction projects (13) Works of study (auction of identical markets to several contractors to obtain different suggestions of solutions) (14) Consulting and technical, technical integrated, relevant scientific and technical consulting, technical essays and analyses not concerning construction projects (15) Advertising, information and public relations (16) Cleanings of buildings and property management (17) Edition and impression (18) Sewage and refuse disposal, sanitation and analogous services

Construction services (Switzerland): (1) Preparation of the sites and work-sites of construction (2) Construction of buildings (3) Construction of civil works (4) Assembly and construction of prefabricated works (5) Works of specialized businesses of construction (6) Putting installations (7) Secondary work and building finishing (8) Housing and credit lease concerning equipments of construction or of demolition, personnel works

Source: WTO (various years)

Note: (1) The numbers in parentheses refer to goods and services sectors referred to in the paper (2) The list of Swiss services and construction services has been translated into English from French 


\section{Table A3: Data description for the empirical model}

\begin{tabular}{|c|c|c|c|c|c|c|c|c|c|c|}
\hline \multirow{2}{*}{$\begin{array}{l}\text { Country } \\
\text { Variable description }\end{array}$} & \multicolumn{5}{|c|}{$\sim \sim \sim \sim \sim \sim \sim \sim$ Japan } & \multicolumn{5}{|c|}{ 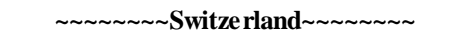 } \\
\hline & Obs & Mean & Std. Dev. & Min & $\operatorname{Max}$ & Obs & Mean & Std. Dev. & Min & Max \\
\hline \multicolumn{11}{|l|}{ Procurement-specific variables } \\
\hline Total procurement (real USD mn) & 326 & 40957.0 & 23755.9 & 7194 & 88360 & 334 & 1395.5 & 541.3 & 642.5 & 2200.7 \\
\hline AT procurement (real USD mn) & 326 & 585.8 & 1913.9 & 0 & 16141.9 & 334 & 18.7 & 45.8 & 0.0 & 381.2 \\
\hline Foreign procurement (real USD mn) & 326 & 30.5 & 65.2 & 0 & 545.5 & 334 & 6.1 & 16.3 & 0.0 & 130.4 \\
\hline FP share in AT procurement & 312 & 0.14 & 0.20 & 0 & 1 & 258 & 0.32 & 0.35 & 0.0 & 1.0 \\
\hline Relative demand (value) & 326 & 0.03 & 0.08 & 0 & 0.51 & 334 & 0.04 & 0.1 & 0.0 & 0.5 \\
\hline Relative demand (number) & 326 & 0.03 & 0.09 & 0 & 0.76 & 334 & 0.04 & 0.1 & 0.0 & 0.5 \\
\hline Number of contracts (total) & 326 & 647.9 & 2670.4 & 0 & 34692 & 334 & 26.2 & 60.0 & 0.0 & 612.0 \\
\hline Number of contracts (domestic) & 308 & 609.8 & 2728.5 & 1 & 34688 & 239 & 20.6 & 38.6 & 1.0 & 230.0 \\
\hline Number of contracts (foreign) & 326 & 71.8 & 171.8 & 0 & 1202 & 334 & 11.5 & 43.9 & 0.0 & 537.0 \\
\hline Average contract size domestic (real USD mn) & 308 & 1.3 & 2.7 & 0.032 & 27.9 & 239 & 0.8 & 0.89 & 0.02 & 7.0 \\
\hline Average contract size foreign (real USD mn) & 229 & 1.2 & 2.1 & 0.01 & 16.9 & 169 & 1.0 & 3.6 & 0.0 & 46.9 \\
\hline \multicolumn{11}{|l|}{ Sector-specific variables } \\
\hline Gross output (real USD mn) & 297 & 125469.2 & 176321.1 & 2476.1 & 1100000 & 192 & 15173.6 & 16234.8 & 0.0 & 82000.9 \\
\hline Imports (real USD mn) & 281 & 9354.3 & 9311.2 & 135.7 & 37792.9 & 292 & 3084.4 & 2333.0 & 32.2 & 12015.8 \\
\hline Exports (real USD mn) & 281 & 15350.0 & 19552.4 & 274 & 121150 & 292 & 3655.5 & 4454.1 & 7.1 & 22003.1 \\
\hline Import propensity & 281 & 0.15 & 0.16 & 0.004 & 0.95 & 175 & 1 & 1.7 & 0.0007 & 7.6 \\
\hline Export propensity & 281 & 0.25 & 0.32 & 0.004 & 2.6 & 175 & 0.45 & 0.38 & 0.035 & 1.9 \\
\hline Number of export destinations & 283 & 193.1 & 90.2 & 21 & 430 & 308 & 185.2 & 110.2 & 4 & 490 \\
\hline Number of firms & 219 & 13233.5 & 15860.9 & 56.6 & 70291 & 65 & 1490.6 & 1379.8 & 93.0 & 4615.0 \\
\hline Employment & 297 & 741640.9 & 1307371.0 & 14231 & 7000000 & 198 & 83580.0 & 94245.5 & 2582.0 & 453900.0 \\
\hline Output per employee, APL (real USD) & 297 & 0.2 & 0.1 & 0.05 & 0.74 & 175 & 0.2 & 0.1 & 0.0 & 0.5 \\
\hline Simple Avg. Appd. Tariff & 201 & 1.9 & 3.6 & 0 & 18 & & & & & \\
\hline Import-wted. Appd. Tariff & 157 & 2.1 & 3.4 & 0 & 16 & & & & & \\
\hline Simple Avg. MFN Tariff & 201 & 2.4 & 4.0 & 0 & 20 & & & Tariffs $=$ & & \\
\hline Import-wted. MFN Tariff & 169 & 2.6 & 4.0 & 0 & 18 & & & & & \\
\hline No. of tariff lines & 197 & 405.3 & 572.2 & 38 & 2412 & & & & & \\
\hline \multicolumn{11}{|l|}{ Macroeconomic variables } \\
\hline Annual GDP growth rate $(\%)$ & 326 & 1.1 & 1.8 & -2 & 5.2 & 334 & 1.3 & 1.4 & -0.9 & 3.8 \\
\hline Unemployment rate $(\%)$ & 326 & 4.0 & 1.2 & 2 & 5.4 & 334 & 3.1 & 1.0 & 0.5 & 4.1 \\
\hline REER & 326 & 86.7 & 7.3 & 75.0 & 100 & 334 & 104.9 & 4.0 & 100.0 & 114.4 \\
\hline \multicolumn{11}{|l|}{ Political economy variables } \\
\hline Election year dummy & 326 & 0.3 & 0.5 & 0 & 1 & 334 & 0.3 & 0.5 & 0 & 1 \\
\hline Year preceding election year dummy & 326 & 0.3 & 0.4 & 0 & 1 & 334 & 0.3 & 0.5 & 0 & 1 \\
\hline UR GPA dummy & 326 & 0.7 & 0.4 & 0 & 1 & 334 & 0.7 & 0.5 & 0 & 1 \\
\hline
\end{tabular}

Source: WTO (various years); World Bank, World Development Indicators (various years); Nicita \& Olarreaga (2006); OECD STAN (various years); OECD Trade in Services (various years); UN Comtrade (various years); IIDE (2009); UNIDO (2010); own calculations 